U.S. DEPARTMENT OF THE INTERIOR

U.S. GEOLOGICAL SURVEY

\title{
Preliminary Volcano-Hazard Assessment for Great Sitkin Volcano, Alaska
}

Open-File Report 03-112

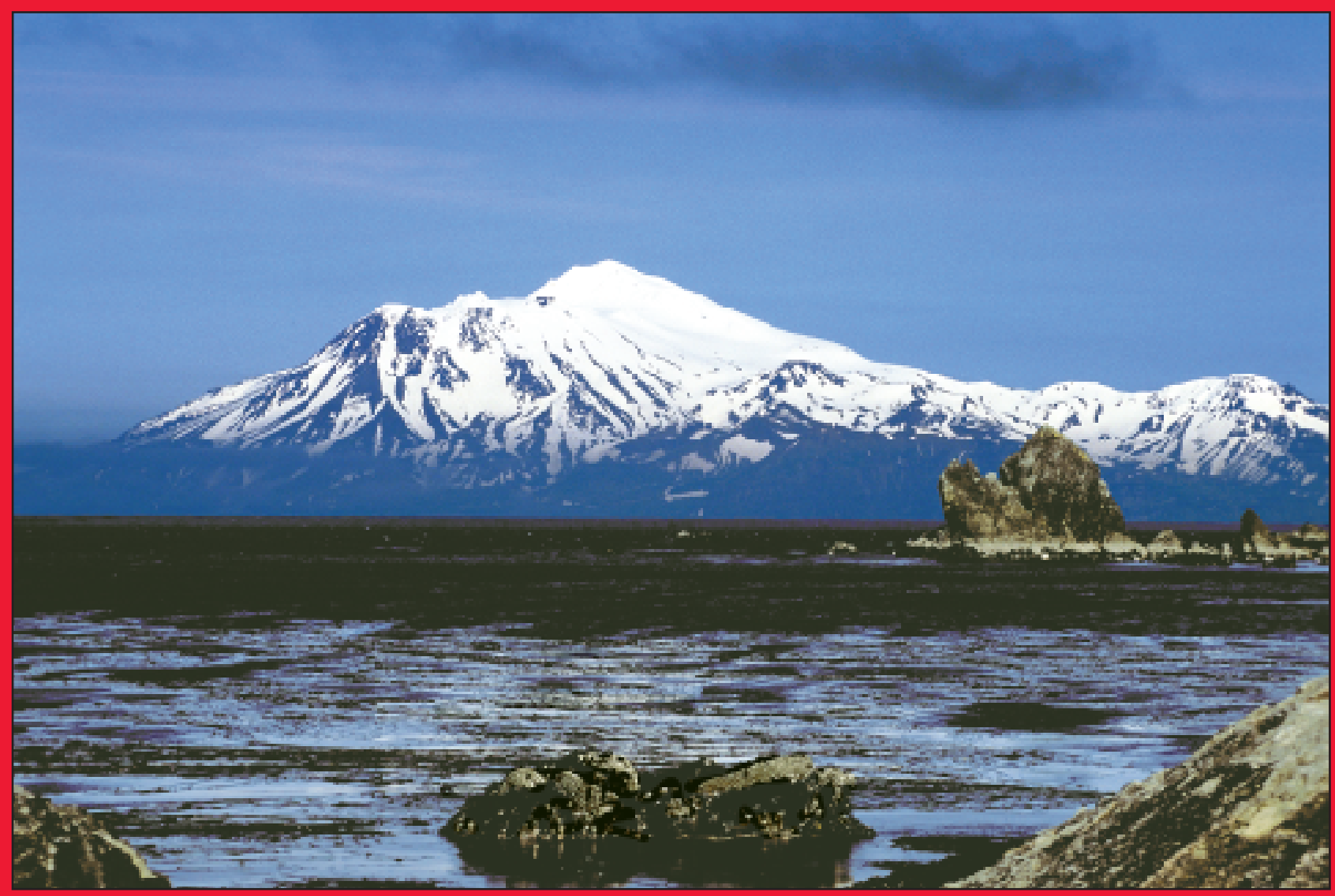

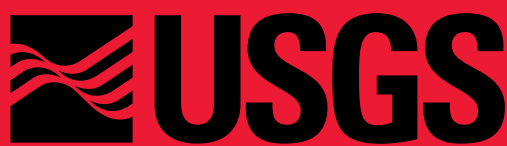

science for a changing world
This report is preliminary and subject to revision as new data become available. It does not conform to U.S. Geological Survey editorial standards or with the North American Stratigraphic Code.

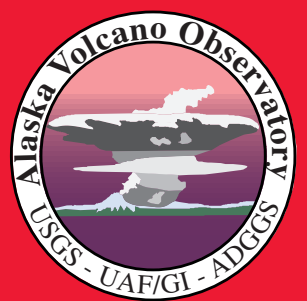


The Alaska Volcano Observatory (AVO) was established in 1988 to monitor dangerous volcanoes, issue eruption alerts, assess volcano hazards, and conduct volcano research in Alaska. The cooperating agencies of AVO are the U.S. Geological Survey (USGS), the University of Alaska Fairbanks Geophysical Institute (UAFGI), and the Alaska Division of Geological and Geophysical Surveys (ADGGS). AVO also plays a key role in notification and tracking eruptions on the Kamchatka Peninsula of the Russian Far East as part of a formal working relationship with the Kamchatkan Volcanic Eruptions Response Team.

Cover photograph: Great Sitkin Volcano from the north shore of Adak Island, July 2000. Photograph by C.F. Waythomas, U.S. Geological Survey. 


\section{Preliminary Volcano-Hazard Assessment for Great Sitkin Volcano, Alaska}

By Christopher F. Waythomas, Thomas P. Miller, and Christopher J. Nye

U.S. GEOLOGICAL SURVEY

Open-File Report 03-112

Alaska Volcano Observatory

Anchorage, Alaska

2003 


\title{
U.S. DEPARTMENT OF THE INTERIOR \\ GALE A. NORTON, Secretary
}

\author{
U.S. GEOLOGICAL SURVEY
}

CHARLES G. GROAT, Director

Any use of trade, product, or firm names in this publication is for descriptive purposes only and does not imply endorsement by the U.S. Government

Copies of this report can be obtained from either of the following sources:

U.S. Geological Survey

Information Services

Building 810

Box 25286, Federal Center

Denver, CO 80225-0286

(Tel. 303-236-7477 or 800-USA-MAP)
U.S. Geological Survey

Earth Science Information Center

4230 University Drive

Anchorage, AK 99508

(Tel. 907-786-7011)

\section{How to contact the Alaska Volcano Observatory:}

U.S. Geological Survey

4200 University Drive

Anchorage, AK 99508

(Tel. 907-786-7497)

(Fax 907-786-7425)

(Internet: http://www.avo.alaska.edu) 


\section{CONTENTS}

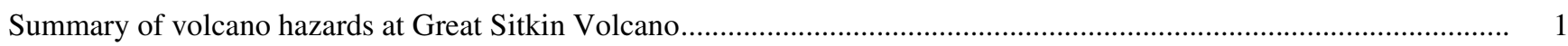

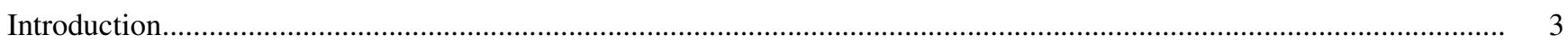

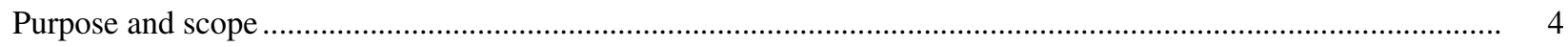

Prehistoric eruptive activity at Great Sitkin Volcano …..........................................................................................

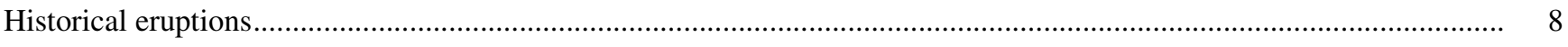

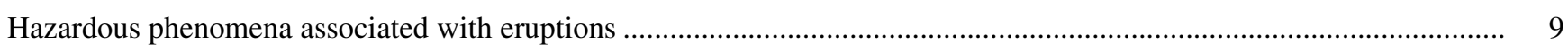

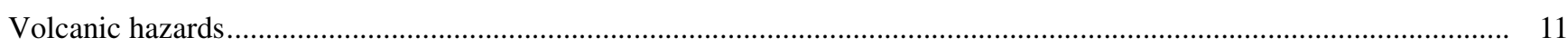

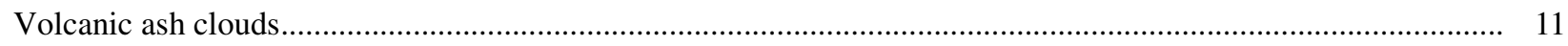

Volcanic ash fallout and volcanic bombs (ballistics) .................................................................................... 11

Lahars, lahar-runout flows, and floods................................................................................................ 13

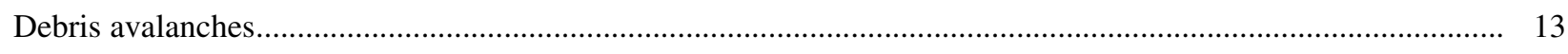

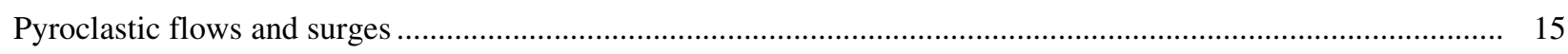

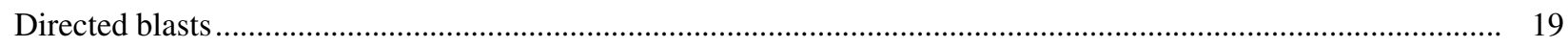

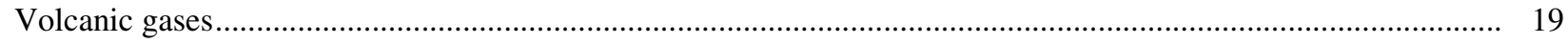

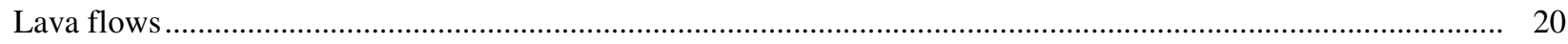

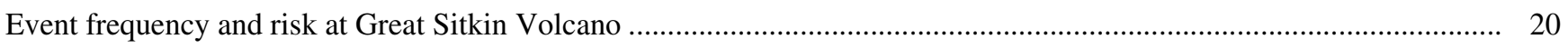

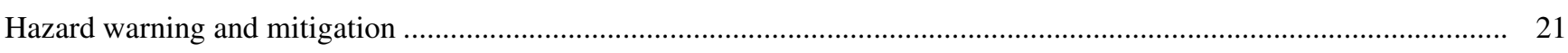

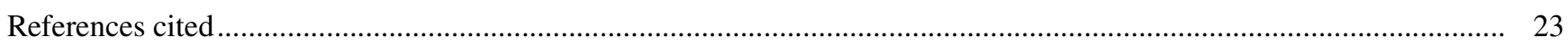

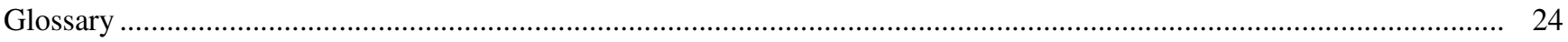

\section{PLATE}

1. Preliminary volcano-hazard assessment for Great Sitkin Volcano, Alaska....................................... [ [In pocket]

\section{FIGURES}

1. Map showing location of Great Sitkin Volcano in relatin to other volcanoes on the Aluetian arc of Alaska....... 3

2. Map showing location of Great Sitkin Volcano and nearby volcanic islands of the western Aleutian Islands .... 4

3. Photograph of Great Sitkin Volcano from the north shore of Adak Island...................................................... 5

4. Map showing generalized geology of Great Sitkin Volcano ......................................................................

5. Chart outlining Holocene eruptive history of Great Sitkin Volcano ............................................................... 7

6. Photographs of Great Sitkin Volcano crater in 1974(A) and 1945 (B) ........................................................ 9

7. Schematic showing hazards associated with eruptions of stratovolcanoes..................................................... 10

8. Photograph of ash-laden eruption column, February 1974, at Great Sitkin Volcano ......................................... 11

9. Map showing hazards from ash fall at Great Sitkin Volcano …................................................................. 12

10. May showing hazards from lahars, lahar-runout flows, and floods at Great Sitkin Volcano ............................. 14

11. Schematic cross sections of Great Sitkin Volcano................................................................................. 15 


\section{FIGURES-Continued}

12. Map showing approximate extent of subaqueous debris-avalanche deposits northwest of Great Sitkin Volcano 16

13. Map showing areas of Great Sitkin Island that could be swept by debris avalanches and rockfall .................. 17

14. Map showing areas of Great Sitkin Island that could be affected by pyroclastic flows .................................. 18

15. Map showing areas near Great Sitkin Island that could be affected by directed blasts ................................. 20

16. Map showing principal North Pacific air routes in relation to Great Sitkin Volcano.........................................21

\section{TABLES}

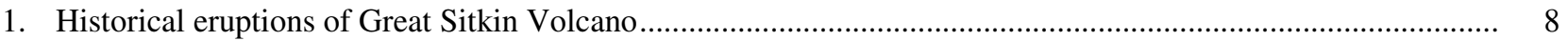

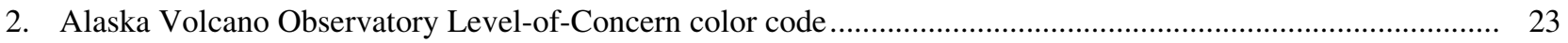

\section{CONVERSION FACTORS and VERTICAL DATUM}

\begin{tabular}{rll}
\hline Multiply & by & To obtain \\
\hline millimeter $(\mathrm{mm})$ & 0.03937 & inch \\
meter $(\mathrm{m})$ & 3.281 & foot \\
kilometer $(\mathrm{km})$ & 0.6214 & mile \\
cubic kilometer $\left(\mathrm{km}^{3}\right)$ & 0.2399 & cubic mile \\
meter per second $\left(\mathrm{m}^{\mathrm{s}}\right)$ & 3.281 & foot per second \\
cubic meter per second $\left(\mathrm{m}^{3} / \mathrm{s}\right)$ & 35.31 & cubic foot per second \\
\hline
\end{tabular}

In this report, temperature is reported in degrees Celsius $\left({ }^{\circ} \mathrm{C}\right)$, which can be converted to degrees Fahrenheit $\left({ }^{\circ} \mathrm{F}\right)$ by the equation

$$
\left.{ }^{\circ} \mathrm{F}=\left(1.8 \mathrm{X}^{\circ} \mathrm{C}\right)+32\right)
$$

Sea level: In this report, "sea level" refers to the National Geodetic Vertical Datum of 1929 (NGVD of 1929, formerly called "Sea-Level Datum of 1929"), which is derived from a general adjustment of the first-order leveling networks of the United States and Canada. In the area of this report, datum is mean lower low water. 


\title{
Preliminary Volcano-Hazard Assessment for Great Sitkin Volcano, Alaska
}

\author{
By Christopher F. Waythomas, Thomas P. Miller, and Christopher J. Nye
}

SUMMARY OF VOLCANO HAZARDS AT GREAT SITKIN VOLCANO

\section{- Volcanic ash clouds}

Clouds of fine volcanic ash will drift away from the volcano with the wind, which generally blows from the west. Ash clouds from Great Sitkin Volcano are a hazard to all aircraft downwindfrom the volcano. Airborne volcanic ash can drift thousands of kilometers from its source volcano and typically will remain in the atmosphere for days to months. Ash from future eruptions could interfere with regional air travel, especially during a large, sustained eruption

\section{- Volcanic ash fallout}

Ash fallout from historical and prehistorical eruptions of Great Sitkin Volcano reached all parts of Great Sitkin Island. Fine ash was deposited on the flanks of the volcano during the last eruption in 1974. Heavy ash fall can disrupt many human activities, interfere with power generation, affect visibility, and damage electrical components and equipment.

\section{- Ballistics}

During most eruptions, cobble-sized and larger fragments of volcanic rock may be explosively ejected from the vent. These particles are called volcanic bombs or ballistics. Ballistic fallout could occur within a few kilometers of the vent and would be hazardous to people or aircraft near the volcano.

\section{- Lahar and lahar-runout flows}

Hot, volcanic debris interacts with snow and ice may generate fast-moving slurries of water, mud, rocks, and sand. These flows, called lahars, are expected to form during most future eruptions of Great Sitkin Volcano. Lahars will follow streams and drainageways and could flow to the coastline and into the sea on the north, west, and east sides of the volcano.

\section{- Pyroclastic flows and surges}

Hot, granular material expelled from the volcano may travel rapidly down the volcano flanks as flows of volcanic debris called pyroclastic flows and surges. These flows commonly travel along valleys, gullies, and other low-lying topography and are expected to reach the coastline on the north and west sides of the volcano during most eruptions. Pyroclastic flows and surges pose little hazard except to people on or near the volcano during an eruption. These flows may extend out over water.

\section{THE ALASKA VOLCANO-HAZARD ASSESSMENT SERIES}

This report is part of a series of volcano-hazard assessment reports being prepared by the Alaska Volcano Observatory. The reports are intended to describe the nature of volcanic hazards at Alaska volcanoes and show the extent of hazardous areas with maps, photographs, and other appropriate illustrations. Considered preliminary, these reports are subject to revision as new data become available. 
Other hazardous phenomena that may occur but are uncommon during typical eruptions of Great Sitkin Volcano include the following:

\section{- Debris avalanches}

A debris avalanche is a rapidly moving mass of solid or incoherent blocks, boulders, and gravel initiated by a large-scale failure of the volcano flank. Debris-avalanche deposits are present on the volcano but are small in volume. Debris avalanches could form during future eruptions of Great Sitkin Volcano, but they are not likely to be voluminous.

\section{- Directed blasts}

A directed blast is a lateral explosion of the volcano caused by rapid release of internal pressure commonly caused by a slope failure or landslide. Directed blasts are rare volcanic events. Evidence for a directed blast has not been identified at the Great Sitkin Volcano.

\section{- Volcanic gases}

Some volcanoes emit gases in concentrations that are harmful to humans. The vent area inside the crater on Great Sitkin Volcano and a zone of fumaroles on the south flank of the volcano are areas where harmful gases could collect. However, the frequently windy conditions around the volcano will likely prevent the buildup of volcanic gases. Thus, the hazard from volcanic gases is minimal unless one is in or near the crater or fumarole zone for prolonged periods of time.

\section{- Lava flows}

Streams of molten rock (lava) may extend a few kilometers from the vent. Lava flows move slowly, only a few tens of meters per hour, and pose little hazard to humans. Some lava flows may develop steep, blocky fronts, and avalanching of blocks could be hazardous to someone close to the front of an advancing lava flow.

\section{SUGGESTIONS FOR READING THIS REPORT}

Readers who want a brief overview of volcano hazards at the Great Sitkin Volcano are encouraged to read the summary section and consult plate 1 and the illustrations. Individual sections of this report provide a slightly more comprehensive overview of the various hazards at the Great Sitkin Volcano. A glossary of relevant geologic terms is included. Additional information about the Great Sitkin Volcano can be obtained by consulting the references cited at the end of this report or by visiting the Alaska Volcano Observatory Web site (URL: <http://www.avo.alaska.edu>). 


\section{INTRODUCTION}

Great Sitkin Volcano is a composite andesitic stratovolcano on Great Sitkin Island $\left(51^{\circ} 05^{\prime} \mathrm{N}\right.$ latitude, $176^{\circ} 25^{\prime} \mathrm{W}$ longitude), a small (14 x $\left.16 \mathrm{~km}\right)$, circular volcanic island in the western Aleutian Islands of Alaska (fig. 1). Great Sitkin Island is located about 35 kilometers northeast of the community of Adak on Adak Island and 130 kilometers west of the community of Atka on Atka Island (fig. 2). Great Sitkin Volcano is an active volcano and has erupted at least eight times in the past 250 years (Miller and others, 1998). The most recent eruption in 1974 caused minor ash fall on the flanks of the volcano and resulted in the emplacement of a lava dome in the summit crater.

The summit of the composite cone of Great Sitkin Volcano (fig. 3) is 1,740 meters above sea level. The active crater is somewhat lower than the summit, and the highest point along its rim is about 1,460 meters above sea level (fig. 3). The crater is about 1,000 meters in diameter and is almost entirely filled by a lava dome emplaced in 1974. An area of active fumaroles, hot springs, and bubbling hot mud is present on the south flank of the volcano at the head of Big Fox Creek (plate 1), and smaller ephemeral fuma- roles and steam vents are present in the crater and around the crater rim. The flanking slopes of the volcano are gradual to steep and consist of variously weathered and vegetated blocky lava flows that formed during Pleistocene and Holocene eruptions. The modern edifice occupies a caldera structure that truncates an older sequence of lava flows and minor pyroclastic rocks on the east side of the volcano. The eastern sector of the volcano includes the remains of an ancestral volcano that was partially destroyed by a northwest-directed flank collapse.

In winter, Great Sitkin Volcano is typically completely snow covered. Should explosive pyroclastic eruptions occur at this time, the snow would be a source of water for volcanic mudflows or lahars. In summer, much of the snowpack melts, leaving only a patchy distribution of snow on the volcano. Glacier ice is no longer present on the volcano or on other parts of Great Sitkin Island as previously reported by Simons and Mathewson (1955).

Great Sitkin Island is presently uninhabited and is part of the Alaska Maritime National Wildlife Refuge, managed by the U.S. Fish and Wildlife Service. More information about the refuge can be found at http://www.r7.fws.gov/nwr/akmnwr/akmnwr.html.

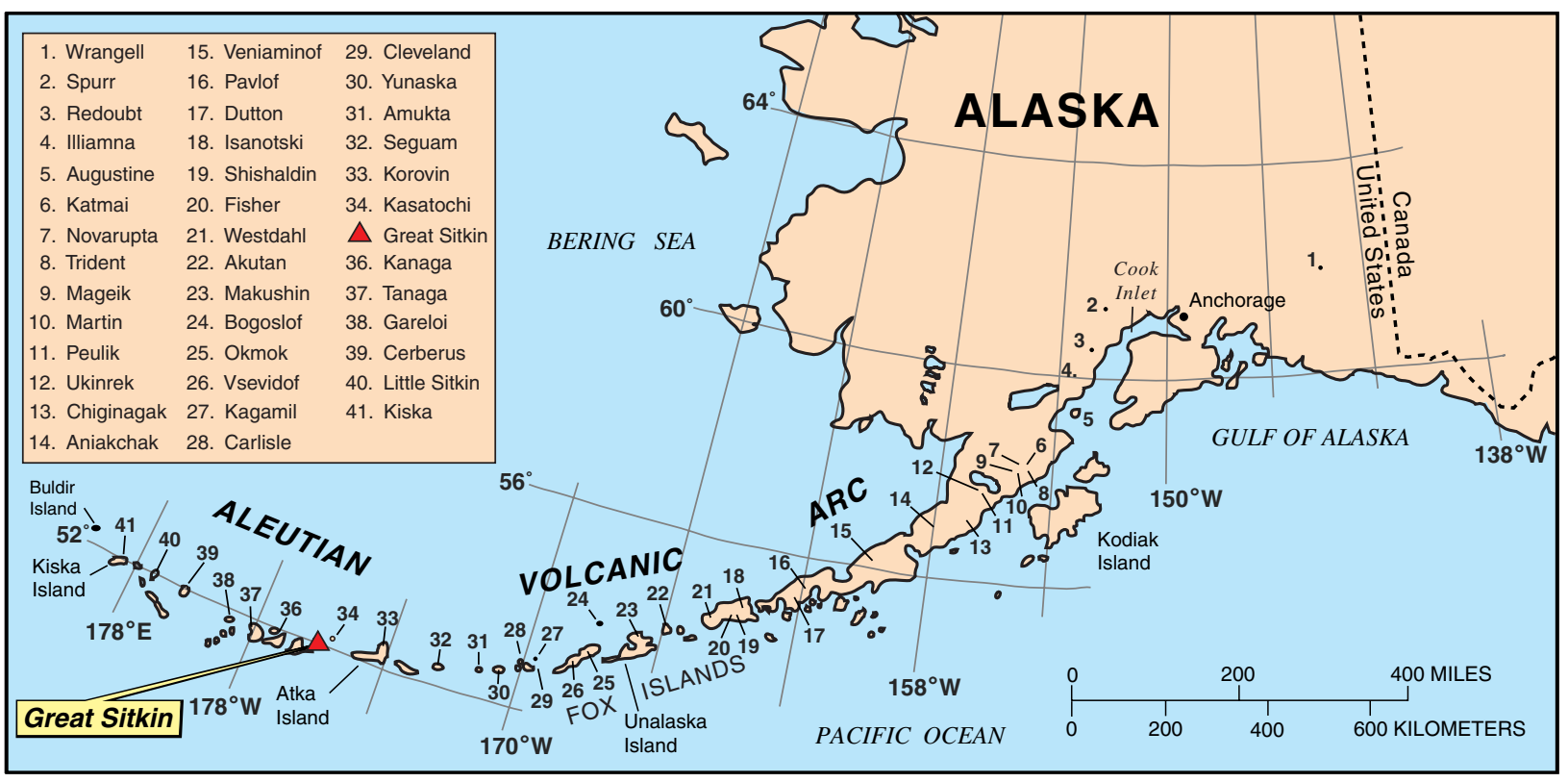

Figure 1. Location of Great Sitkin Volcano in relation to other volcanoes on the Aleutian arc of Alaska. 


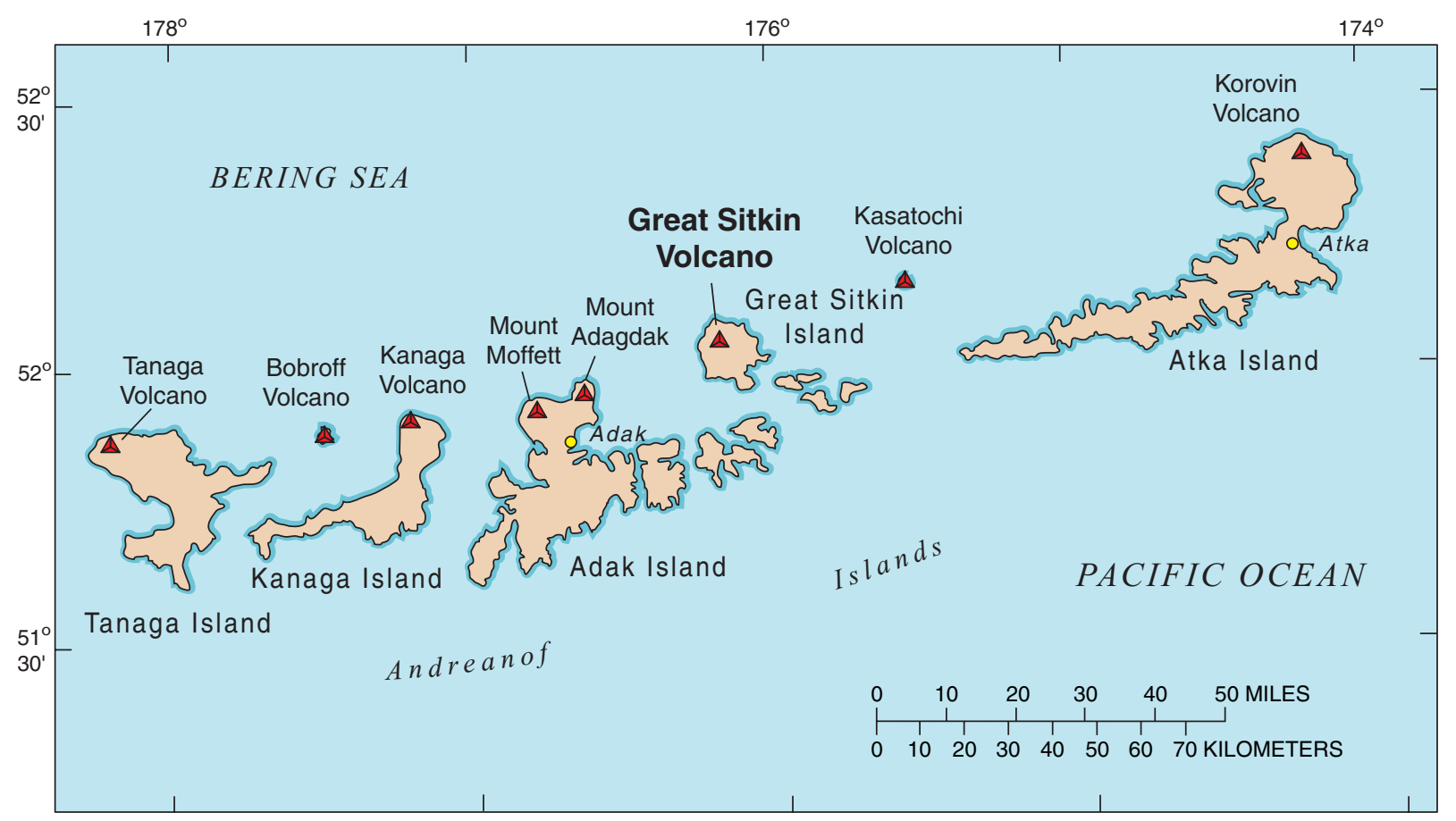

Figure 2. Great Sitkin Island and nearby volcanic islands of the western Aleutian Islands.

The island is remote, often shrouded by clouds and fog, and can be reached only by boat, amphibiouslanding aircraft,or helicopter.

\section{Purpose and Scope}

This report summarizes the principal volcano hazards associated with eruptions of Great Sitkin Volcano based on brief helicopter-supported studies of the volcano by the Alaska Volcano Observatory in 1999 and 2000 and previous studies of the volcano in 1946 (Simons and Mathewson, 1955). Hazardous volcanic phenomena likely to occur on or near the volcano, as well as distal effects of eruptions, are described. The present status of monitoring efforts to detect volcanic unrest and the procedure for eruption notification and dissemination of information also are presented. A series of maps and illustrations that show potentially hazardous areas are included. A glossary of geologic terms is at the end of the report. Terms defined in the glossary are set in different type (italic or roman) at their first appearance in the text.

\section{PREHISTORIC ERUPTIVE ACTIVITY AT GREAT SITKIN VOLCANO}

Great Sitkin Volcano is a composite stratocone situated on the northern part of Great Sitkin Island (fig.2). The volcano is composed primarily of andesite and basaltic andesite lava flows, andesite lava domes, and pyroclastic-flow and lahar deposits (fig.4).The modern vent sits within an arcuate-shaped, calderalike structure open to the northwest and defined by a subdued headscarp that truncates a series of lava flows on the northeast side of the island (unit Qlf, fig.4). A series of lava flows and lava domes make up the present edifice of the volcano, which covers the northwest sector of Great Sitkin Island (fig.4). The southern part of Great Sitkin Island consists of two groups of volcanic rocks of Tertiary (?) and older age that include mainly andesite and basalt lava flows, agglomerate, pyroclastic rocks, and tuff (Simons and Mathewson, 1955). The older group of rocks is part of the Finger Bay volcanics, a predominantly andesitic to basaltic greenstone found on Adak, Great Sitkin, and adjacent islands (Coats, 1956).

The Finger Bay volcanics are unconformably overlain by an undeformed succession of volcanic 


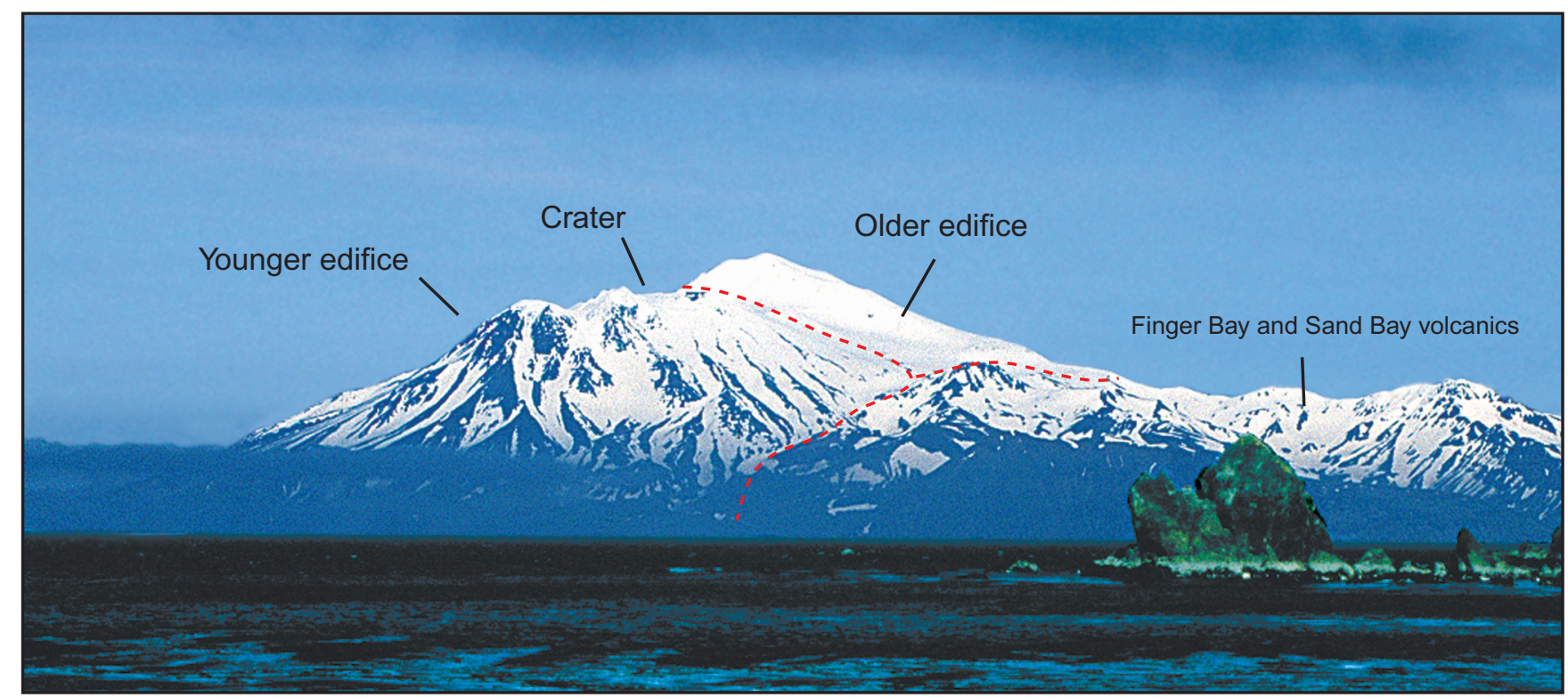

Figure 3. Great Sitkin Volcano from the north shore of Adak Island. Photograph by author C.F. Waythomas, July 2000.

rocks called the Sand Bay volcanics (Simons and Mathewson, 1955). These rocks make up most of the southern part of Great Sitkin Island and are the remnants of an ancestral shield volcano whose edifice probably was located near the present cone. The age of the Sand Bay volcanics is not known, but Simons and Mathewson (1955) suggest that these rocks are late Tertiary in age.

Studies of Great Sitkin Volcano in 1999 and 2000 yielded new information about the recent eruptive history of the volcano based on stratigraphic analysis of volcanic deposits and radiocarbon dating. Because volcanic activity is generally episodic, long periods of inactivity may be punctuated by periods of rapid deposition of volcanic sediment during eruptions. Vegetation growth and soil development may occur during noneruptive periods, but during eruptions, vegetation and soil may be buried by volcanic deposits, particularly volcanic ash. Over time, a vertical sequence of buried soils and vegetation, volcanic deposits, and volcanic ash developes. A stratigraphic sequence of volcanic deposits evolves in this manner over many thousands of years, and it is possible to determine the eruptive history of the volcano by dating buried soils, plant remains, and sometimes charcoal, either in or associated with the volcanic deposits. By systematically dating volcanic deposits around the volcano, it is possible to determine the significant periods of eruptive activity and to define the Hocene eruptive history of the volcano.
Radiocarbon dating of prominent volcanic ash layers, lahars, and pyroclastic-flow deposits indicates that the volcano has erupted explosively many times during the past 9,000 years (fig. 5). Deposits of pumice-rich lapilli tephra are common in many locations on southern Great Sitkin Island, and these deposits record significant explosive eruptions of the volcano. The lapilli-producing eruptions were probably single or multiple explosive bursts associated with extensive ash fallout, localized pyroclastic flows, lahars, and lava flows. At least eight such eruptions have occurred in the past 9,000 years and as recently as within the past 500 years (fig. 5 ). Smaller eruptions also occurred, and these generally produced thinner, finer grained, and less extensive volcanic ash deposits, minor pyroclastic flows, and possibly lahars. Stratigraphic profiles of volcanic ash on the southern part of Great Sitkin Island contain a number of silt-sized, thin-bedded, volcanic ash layers. Many of these deposits were formed by minor, short-lived eruptions of Great Sitkin Volcano, but some of the ash beds could be from other volcanoes west of Great Sitkin Island, such as Kanaga and Tanaga volcanoes, and possibly Mt. Moffett on Adak Island (fig. 2).

The modern edifice of Great Sitkin Volcano has developed within a semicircular volcanic structure known as a caldera (fig. 4). The caldera is open to the north-northwest and is evidence for a large-scale collapse of a portion of an older volcanic cone on Great Sitkin Island. In other parts of the Aleutian volcanic 


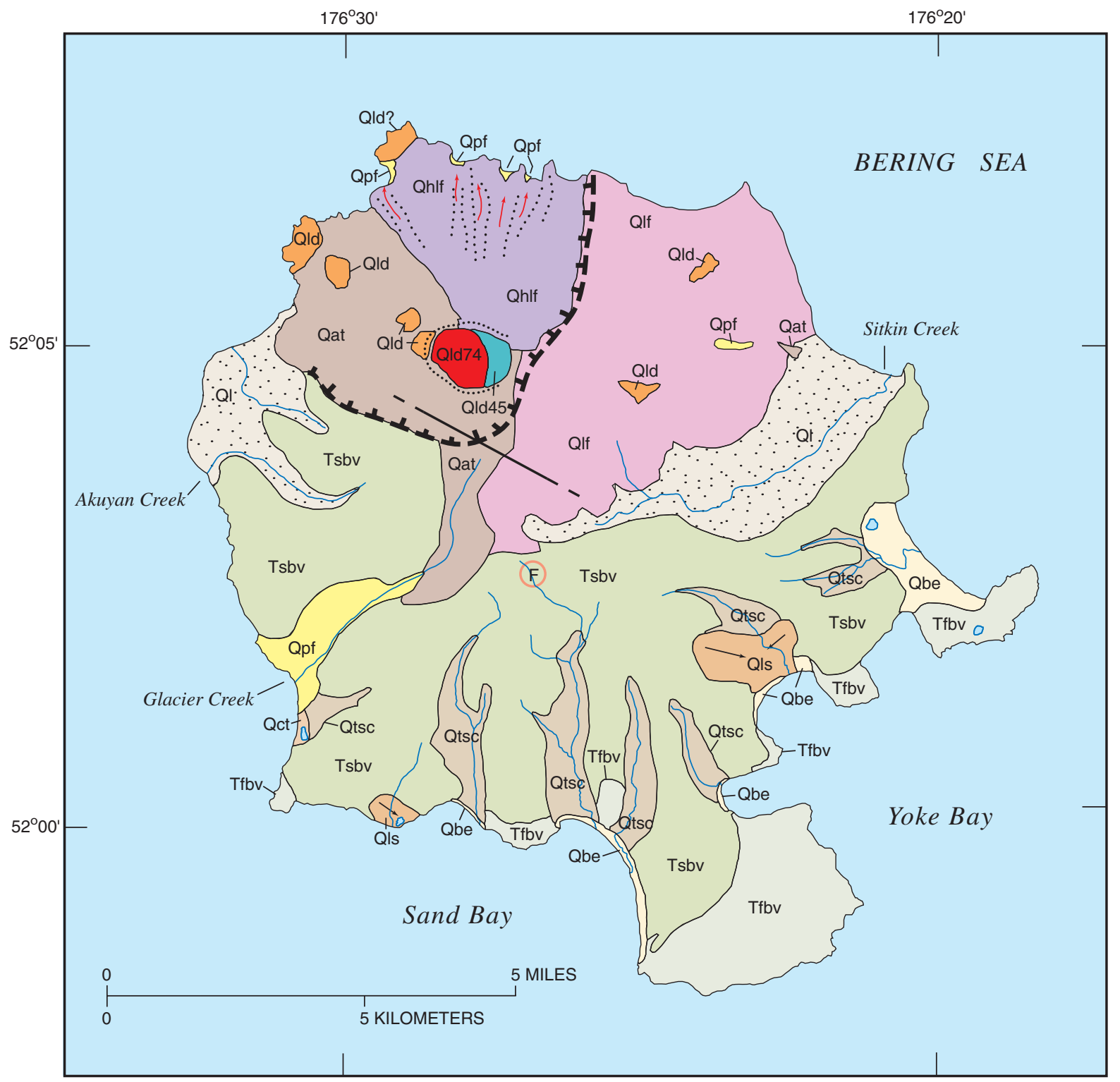

Figure 4. Generalized geology of Great Sitkin Volcano.

arc (fig. 1), large, circular calderas have formed by gravitational collapse during or following large-volume pyroclastic eruptions (Miller and Smith, 1987). Typically, these caldera-forming eruptions generate voluminous, radially spreading pyroclastic flows that form sheet-like accumulations of pyroclastic debris surrounding the volcano that extend for many tens of kilometers beyond the vent. Such deposits have not been found on Great Sitkin Island, indicating that the caldera structure formed by some other process. On the basis of our recent studies of the volcano, we suggest that the caldera structure formed when a major portion of ancestral Great Sitkin Volcano slid seaward.
Long-range sidescan sonar data (Bering Sea EEZSCAN Scientific Staff, 1991) from just offshore to the north of Great Sitkin Island indicate an area of irregular, hummocky topography that extends north from the volcano for about 30 kilometers. The hummocky deposits on the sea floor may be debris-avalanche deposits formed by the collapse of Great Sitkin Volcano. It is not known when the avalanche caldera formed, but our recent studies of the volcano indicate that the bulk of the modern cone is of Holocene age and, therefore, that caldera formation most likely occurred more than 10,000 years ago. 


\section{DESCRIPTION OF MAP UNITS}

Beach and coastal eolian deposits

Qat Talus, avalanche debris and tephra

Qtsc Tephar, soil and colluvium

Qls Landslide deposits

Qct Talus and coarse colluvial deposits

QI Lahar deposits

Qpf Pyroclastic-flow deposits

t 1 Headscarp of flank collapse

+ Flow path of pyroclastic flow

Lava flow lateral levee

_ - - Fault, dashed where uncertain
Qld74 Lava dome emplaced during 1974 eruption

Qld45 Lava dome emplaced during 1945 eruption

Qld Lava domes of unknown age

Qhlf Lava flows of Holocene age

Qlf Lava flows of Holocene and Pleistocene age

Tsbv Sand Bay volcanics

Tfbv Finger Bay volcanics

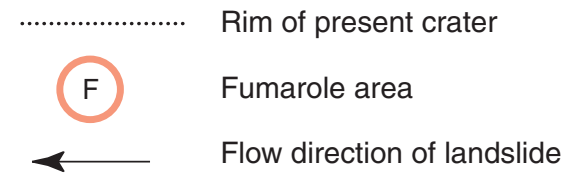

Figure 4. Continued.

\section{TIMING OF VOLCANIC ACTIVITY}

$<280$ yr B.P.

550-700 yr B.P.

1150-1300 yr B.P.

34-3700 yr B.P.

3600-4000 yr B.P.

5900-6600 yr B.P.

7300-7600 yr B.P.

$8400-8900$ yr B.P.

$>9500$ yr B.P.
EVIDENCE

Lahar deposits in Sitkin and Akuyan Creek valleys

Pyroclastic flow deposits in Glacier Creek valley

Pumice lapilli tephra deposits

Lahar deposits in Sitkin Creek valley

Pumice lapilli tephra deposits

Lahar deposits in Sitkin Creek valley

Pumice lapilli tephra deposits

Pumice lapilli tephra deposit (Sandwich ash?)

Pumice lapilli tephra deposit

Pumice lapilli tephra deposit

Pumice and lithic lapilli tephra deposit (Main ash?)

Lahar deposits in Sitkin Creek valley

Pumice lapilli tephra deposits

Pumiceous pyroclastic-flow deposits north of Sitkin Creek valley

Lahar deposits in Sitkin Creek valley

Figure 5. Holocene eruptive history of Great Sitkin Volcano. 
Table 1. Historical eruptions of Great Sitkin Volcano

\begin{tabular}{|c|c|c|}
\hline Date & Eruptive activity & Reference \\
\hline Feb.-Sept. 1974 & $\begin{array}{l}\text { - Minor explosive eruption on Feb. } 19,1974 \\
\text { - Localized ash fall } \\
\text { - Low-level ash cloud }\end{array}$ & $\begin{array}{l}\text { Anchorage Times, Feb. 21, 1974; } \\
\text { Smithsonian Global Volcanism } \\
\text { Program volcanic activity reports } \\
\text { (CSLP 27-74a, CSLP 27-74b) }\end{array}$ \\
\hline $1949-50$ & - Minor ash-producting eruptions & Powers, 1958 \\
\hline 1951 & - Dark, low-level ash cloud & Miller and others, 1998 \\
\hline Aug. 14, 1946 & - Dark, low-level ash cloud & Simons and Mathewson, 1955 \\
\hline March 1945 & $\begin{array}{l}\text { - Extrusion of lava dome within summit crater } \\
\text { - Phreatomagmatic bursts and steam plumes }\end{array}$ & Coats, 1950 \\
\hline Nov. 1933 & - Minor explosive eruption & Coats, 1950 \\
\hline 1904 & • Volcano "fuming" & Coats, 1950; Jaggar, 1927 \\
\hline $1827-29$ & - Intermittent "activity"; small eruptions & Coats, 1950; Becker, 1898 \\
\hline 1792 & - Explosive eruption & Coats, 1950; Grewingk, 1850 \\
\hline $1784(?)$ & • "Activity" & Becker, 1898; Grewingk, 1850 \\
\hline $1760(?)$ & • "Activity" & Grewingk, 1850 \\
\hline
\end{tabular}

Note: Eruptions noted in 1784 and 1760 were attributed to Mount Moffett on Adak Island, but evidence for historical eruptions of this volcano based on field studies has not been found. It is possible that the observer mistook Mount Moffett for Great Sitkin Volcano.

\section{HISTORICAL ERUPTIONS}

Relatively minor episodes of volcanic activity have been reported at Great Sitkin Volcano since its discovery in 1741 during the Bering Expedition (table 1). Additional eruptions that may have occurred were not reported because of the island's remote location and distance from primary maritime routes. Recently completed studies of Great Sitkin Volcano indicated that a major explosive eruption occurred within the past 500 years, possibly in 1792. This eruption produced the present crater; an extensive, pumice-rich, lapilli tephra deposit; and pyroclastic-flow and lahar deposits in several valleys on the flanks of the volcano.

In historical times (about the past 250 years), "smoke" has been reported above Great Sitkin during 1828-29, 1904, 1946, and 1951 ( Simons and Mathewson, 1955). Explosive eruptions occurred in 1792, 1933, 1949-50, and most recently, on February 19, 1974 (Miller and others, 1998). The most notable recorded activity occurred in March 1945 when a circular lava dome, 600-800 meters in diameter, was extruded (fig. 6B; Coats, 1950; Simons and Mathewson, 1955). During twilight hours, a steady glow near the summit of Great Sitkin Volcano was visible from Adak Island for a period of several weeks. Army pilots observed steam clouds rising from the crater, and a strong earthquake was felt at a military installation near Sand Bay sometime during the eruptive episode. On August 14, 1946, a small cloud of "smoke" was observed from Adak Island (Simons and Mathewson, 1955), and ash eruptions during 1949-50 were reported by Powers (1958). Activity at Great Sitkin during 1946-48 was limited to periodic steam emissions from the crater and continued activity at a group of hot springs, mud pots, and fumaroles located about 4 kilometers south of the crater rim (Byers and Brannock, 1949). The hot springs may mark the site of an ancestral volcanic vent older than the modern cone. A lava dome 800-900 meters in diameter was extruded in the crater during the 1974 eruption, and light ash fall occurred on the upper flanks of the volcano. Apparently, most of the lava dome extruded during the 1945 eruption was destroyed or covered by the 1974 eruption. Photographs taken during overflights of the volcano in summer of 1976 (fig. 6A) show steam issuing from parts of the lava dome, indicating that the 1974 dome remained hot for several years after it was extruded. 

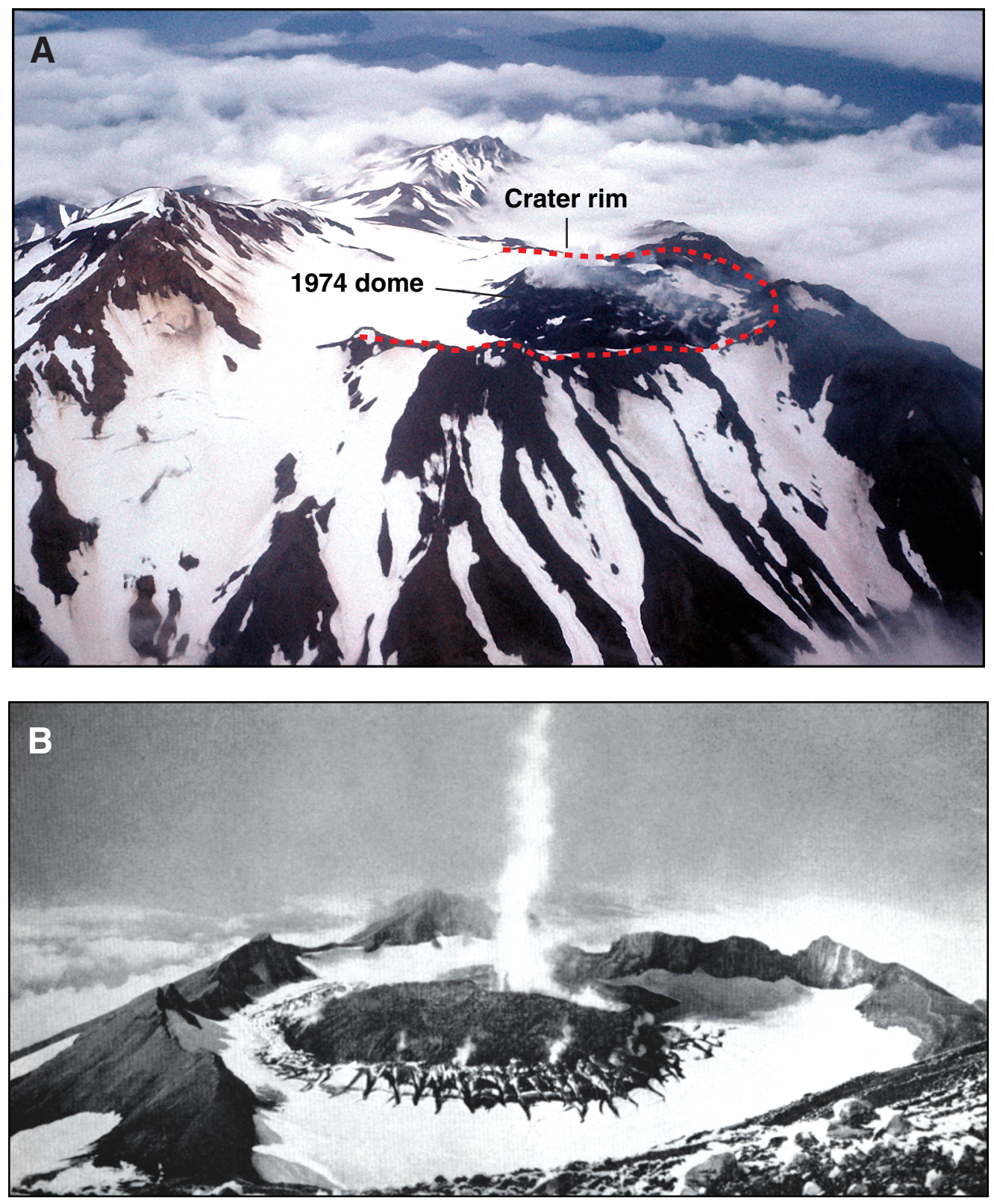

Figure 6. A. Active crater and 1974 lava dome of Great Sitkin Volcano. Photograph by T.P. Miller, U.S. Geological Survey, August 1976. B. Active crater and 1945 lava dome. Photograph by F. Simons, U.S. Geological Survey, September 12, 1946.

\section{HAZARDOUS PHENOMENA ASSOCIATED WITH ERUPTIONS}

A volcano hazard (fig. 7) is any volcanic phenomenon that is potentially threatening to life or property. In general, hazards associated with volcanic eruptions are grouped as proximal or distal, relative to the areas most likely to be affected by specific volcanic phenomena as a function of distance from the vent.
The classification of hazardous phenomena at Great Sitkin Volcano as proximal or distal is an approximate classification because the extent of a particular hazard is, in part, related to the size of the eruption. Thus, a large eruption may cause some phenomena to affect areas well beyond the volcano, whereas during a smaller eruption, the same phenomena may affect areas only in the immediate vicinity of the volcano. 


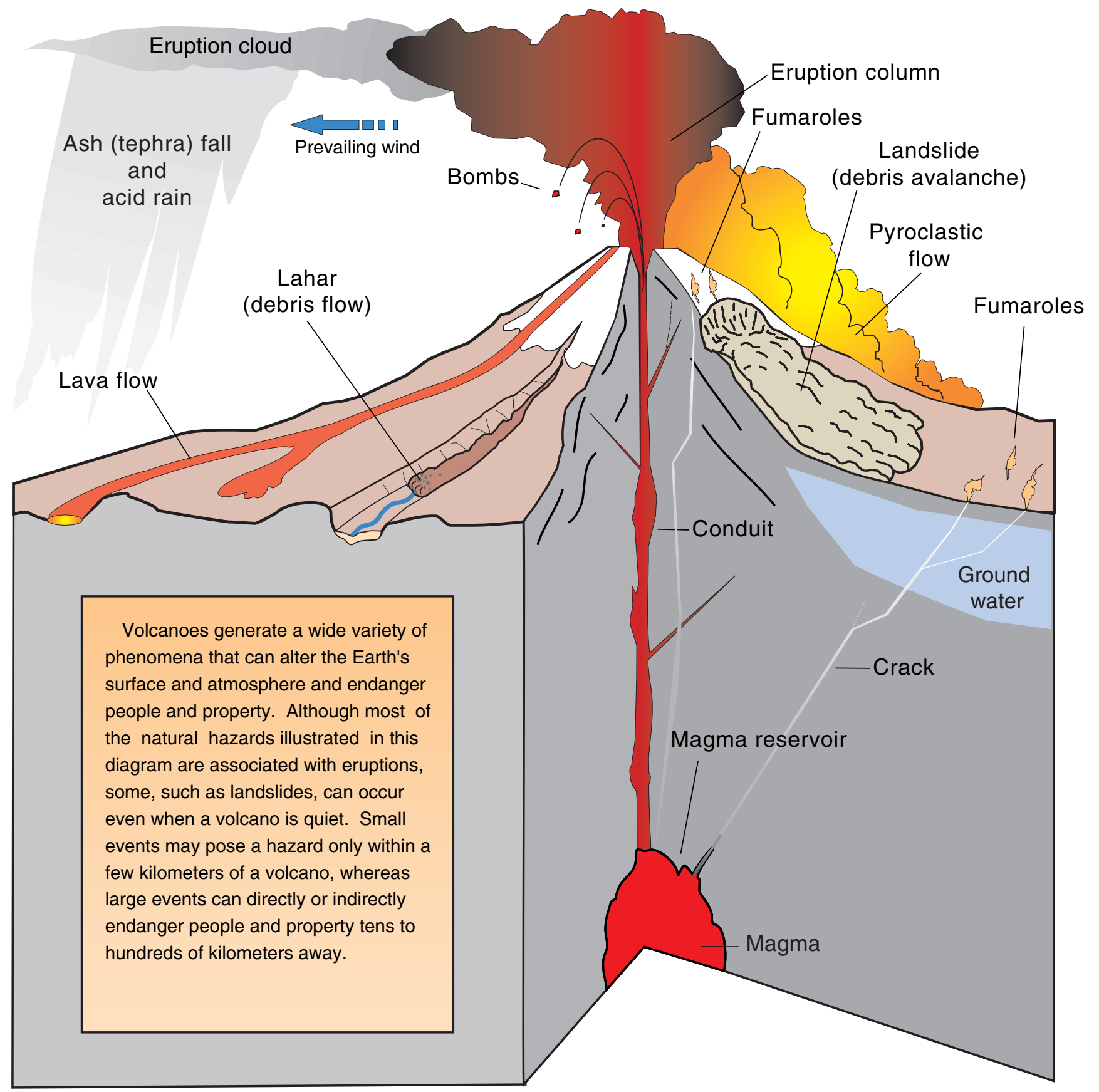

Figure 7. Hazards associated with eruptions of stratovolcanoes (modified from Myers and others, 1997).

Proximal hazards are those phenomena that occur in the immediate vicinity of the volcano, typically within a few tens of kilometers of the active vent. The proximal hazard zone boundary is delineated by the ratio of the volcano summit height $(H)$ to the runout length $(L)$ of on-ground hazardous phenomena such as pyroclastic flows, debris avalanches, and lahars. Typi- cal $H / L$ values range from 0.1 to 0.3 . For Great Sitkin Volcano, the proximal hazard zone includes all of Great Sitkin Island. Life and property within the proximal hazard zone may be at risk during all eruptions, and anyone in this zone would have little or no time to escape from the area once an eruption commenced. 
Distal hazards pose less risk to people because there is usually adequate time for warning and evacuation. This group of hazards affects people and structures that are more than about 10 to 30 kilometers from the volcano. Volcanic ash, either in explosive eruption columns or ash clouds that drift far away from the volcano, can be both a proximal and a distal hazard, especially to aircraft. Fallout of volcanic ash also can be a proximal and a distal hazard.

Deposits and features formed by various volcanic phenomena are shown on the geologic map of Great Sitkin Volcano (fig. 4). The processes that produced these deposits and features generally are confined to the flanks of the volcano. Only volcanic-ash clouds, ash fallout, pyroclastic flows and surges, and unusually large-volume debris avalanches that could initiate tsunamis are most likely to affect areas more than a few kilometers from Great Sitkin Volcano.

\section{VOLCANIC HAZARDS}

\section{Volcanic Ash Clouds}

Explosive eruptions of Great Sitkin Volcano are capable of generating significant quantities of volcanic ash. Typical eruptions of the volcano are likely to produce ash-laden eruption clouds that rise upward into the atmosphere (fig. 8) and drift away from the volcano with the wind. Fine ash particles in an eruption cloud may remain in the atmosphere for days to weeks and can be transported many thousands of kilometers beyond the volcano, depending on the size of the eruption. Volcanic ash clouds are a potential hazard to all aircraft downwind from the volcano (Casadevall, 1994).

Historical eruptions of Great Sitkin Volcano produced small ash clouds, some reaching altitudes up to about 8.5 kilometers (about 28,000 feet) above sea level. These ash clouds most likely drifted east of the volcano with the prevailing winds. The ash clouds had no known effect on air travel and did not result in ash-aircraft encounters, although air traffic in the vicinity of Adak Island could have been disrupted.

If conditions at the volcano do not change significantly, future eruptions of Great Sitkin Volcano are likely to be similar to known historical eruptions, and small, dilute ash clouds rising several kilometers above the volcano should be expected. Eruptions more energetic than these events could produce voluminous ash clouds that could rise 10 to 20 kilometers above sea level and extend downwind for tens to hundreds of kilometers beyond the volcano. Usually, such ash clouds can be detected and monitored by satellite observations.

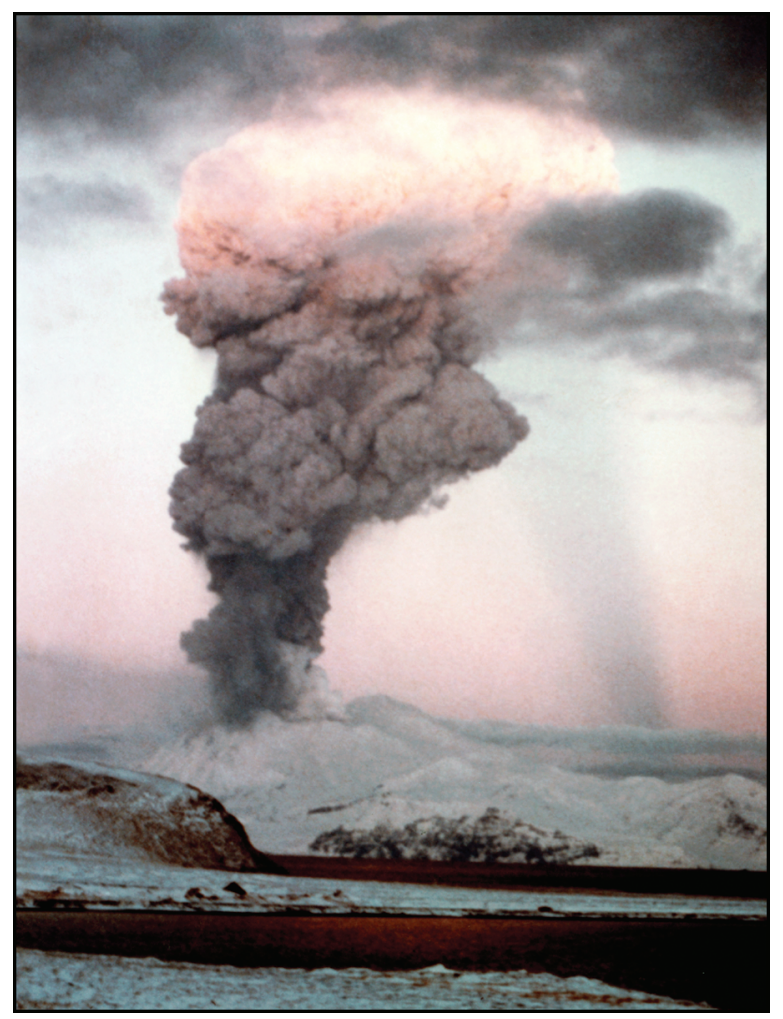

Figure 8. Ash-laden eruption column, February 1974, at Great Sitkin Volcano. Photograph courtesy of Paul W. Roberts, photographer unknown.

\section{Volcanic Ash Fallout and Volcanic Bombs (Ballistics)}

Drifting ash clouds are usually associated with a steady rain or fallout of volcanic ash over areas immediately downwind from the volcano. Accumulations of millimeters to centimeters are common, although thicker amounts of tephra fallout may occur during large eruptions, especially in areas close to the volcano. Few people have ever been killed directly by falling ash, although the weight of a thick ash fall could cause structures to collapse, and inhaling fine ash particles is a health hazard that can be life threatening to some people with respiratory problems. 


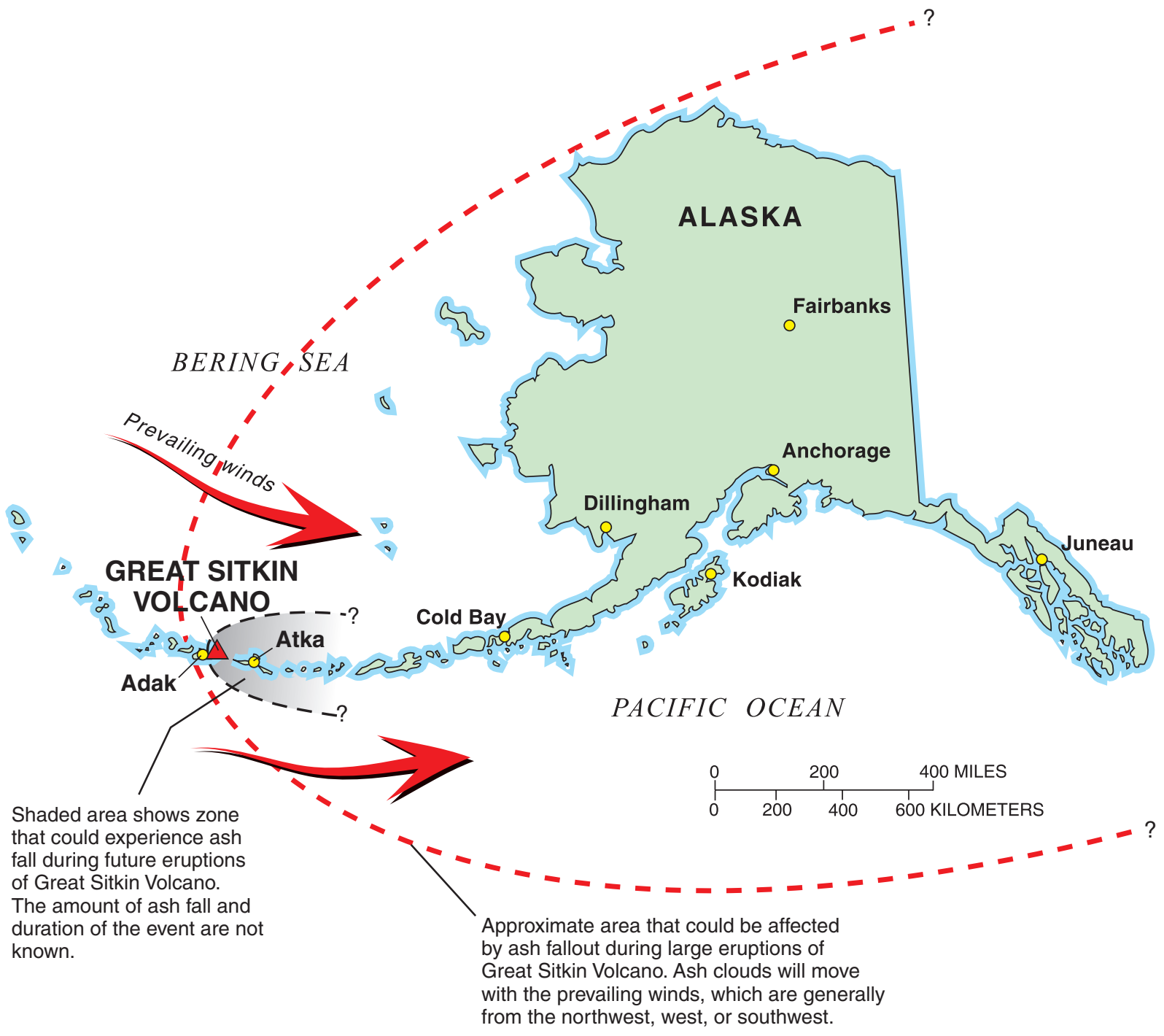

Figure 9. Hazards from ash fall at Great Sitkin Volcano.

Sometimes a "mud rain" results if airborne volcanic ash mixes with falling rain or snow.

The extent of ash fall during historical eruptions of Great Sitkin Volcano is not known. Photographs of the 1974 eruption show that small amounts of fine ash were deposited on the snow-covered flanks of the volcano, but fallout beyond Great Sitkin Island is not known. Depending on the wind conditions at the time of an eruption, ash particles could remain suspended in the air over Great Sitkin Island or periodically be resuspended from accumulations on the ground. This could significantly diminish air quality for days to weeks after the eruption and could impair conditions for air travel to and from the Adak airport.
Wind direction and speed will control the movement of an ash plume and influence ash fallout. The areas most likely to receive ash fall are those in the zone of prevailing winds (fig. 9). The strongest and most consistent winds aloft in the vicinity of Great Sitkin Volcano are westerly winds, which generally will cause deposition of volcanic ash on areas east of the volcano (fig. 9). The thickness of ash fallout will decrease in a downwind direction, but it is impossible to predict how much ash will be produced during an individual eruption. The closest community downwind from Great Sitkin Volcano is Atka, on Atka Island about 140 kilometers east of Great Sitkin Island (fig. 9). Future eruptions similar to historical eruptions of the volcano (table 1) are likely to produce only small 
amounts of volcanic ash, and ash fall on Atka is likely to be minor. However, any amount of ash fall could be disruptive to communities.

It is common during explosive eruptions, and especially those involving water, that blocks and bombs of volcanic rock debris are ejected from the vent as ballistic projectiles. Usually, ballistic fallout occurs in areas near the vent, but in extreme cases, bombs may be ejected distances of 10 to more than 30 kilometers from the vent. Typically, the zone of ballistic fallout is within a few kilometers of the vent, and people or low-flying aircraft would be at risk only within this zone.

\section{Lahars, Lahar-Runout Flows, and Floods}

Most of the volcanoes in Alaska support glaciers or are snow covered most of the year. During many eruptions, hot, pyroclastic debris expelled from the volcano interacts dynamically with the snowpack and causes rapid, extensive melting and water production. As meltwater mixes with unconsolidated volcanic debris on the flanks of the volcano, various types of mass-flow phenomena may occur in stream channels and drainages on the volcano. Most water-rich volcanic mass flows are categorized as debris flows (fig. 7) or, more specifically, as noncohesive (clay-poor) lahars. Lahars consist of a poorly sorted mixture of boulders, sand, silt, and water that has the consistency of wet concrete. As a lahar flows downstream, it typically transforms to a finer grained, watery flow, called hyperconcentrated flow or lahar-runout flow. If enough sediment is lost from a lahar as it flows away from its source, the lahar may transform into a normal streamflow or flood and consist mostly of water.

Lahars also may form directly from water-saturated clay-rich volcanic rock avalanches (Hoblitt and others, 1995; Vallance and Scott, 1997; Vallance, 1999). Such lahars are called cohesive (clay-rich) lahars because the matrix sediment of typical deposits contains more than about 3 percent clay. Lahar deposits formed by this process have not been found at Great Sitkin Volcano.

Great Sitkin Volcano is snow covered almost year round, so eruptions in any season could produce lahars. All flanks of the volcano are susceptible to inundation by lahars, but lahars produced by eruptions from the active crater are likely to affect only those valleys that head on the present cone (fig. 10). Lahars could enter the sea in some valleys (fig. 10) but are unlikely to be flowing fast enough to generate significant waves.

Because lahars, lahar-runout flows, and floods can move rapidly, can be several meters deep, and can transport boulder- and block-sized particles, they would be hazardous to anyone in the flow path. Lahars are not a serious hazard on Great Sitkin Island unless someone is on the volcano or near the coastline during an eruption.

\section{Debris Avalanches}

Volcanic rock or debris avalanches (fig. 7) typically form by structural collapse of the upper part of the volcano. The ensuing avalanche moves rapidly down the volcano flank and forms a bouldery, unsorted gravel deposit many kilometers from the source that may exhibit a characteristic hummocky, irregular surface and cover a broad area. Most debris-avalanche deposits extend up the slopes of the volcano to an arcuate- or horseshoe-shaped scar at or near the volcano summit that marks the zone of collapse and origin of the avalanche. Many large debris avalanches (greater than 1 cubic kilometer in volume) occur during eruptions (Siebert, 1996) but, it is possible for large-scale collapse of a volcanic cone to occur during a distinctly noneruptive period, sometimes as a result of long-term chemical alteration of volcanic rock in the edifice by hot, acidic ground water. A collapse may be triggered by a large earthquake or prolonged, intense rainfall.

Prior to the development of the modern edifice of Great Sitkin Volcano, a portion of the preexisting ancestral cone collapsed and slid into the Bering Sea (fig. 11). It is not known what caused this collapse, but a possible triggering mechanism was intrusion of magma to shallow depths that displaced the north flank of the volcano seaward. A feature that resembles a debris-avalanche deposit is present on the sea floor north of Great Sitkin Island (fig. 12), but its age and characteristics are not known.

Because it is the steepest and most unstable part of the volcano, only the northwest flank of Great Sitkin Volcano is susceptible to being swept by small-scale rockfalls and minor debris avalanches (fig. 13). Most likely are small debris avalanches formed by the collapse of lava-flow fronts and thick piles of spatter that 


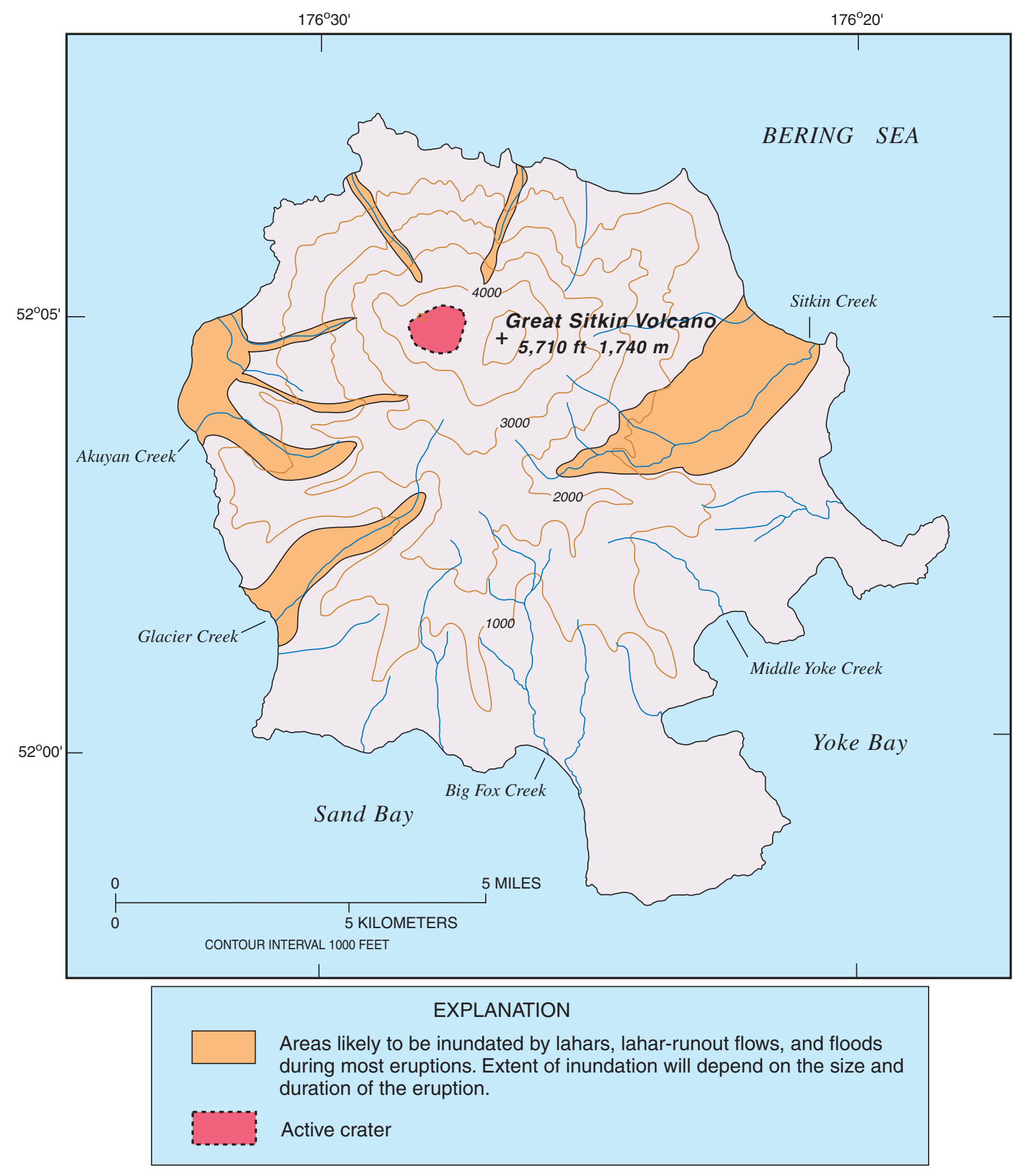

Figure 10. Hazards from lahars, lahar-runout flows, and floods at Great Sitkin Volcano.

accumulate on the crater rim. A large-scale collapse, similar to the one that destroyed the ancestral volcano, is a rare event that occurs on a timescale of several thousand years or more. The edifice of Great Sitkin Volcano is not obviously unstable, and alteration of rocks on the volcano is limited to a small area around the active fumaroles on the south flank of the volcano. A major collapse of the cone is unlikely unless a very large amount of magma begins rising through the crust toward the surface beneath the cone. Thus, the hazard from debris avalanches is minor unless conditions at the volcano change significantly. 

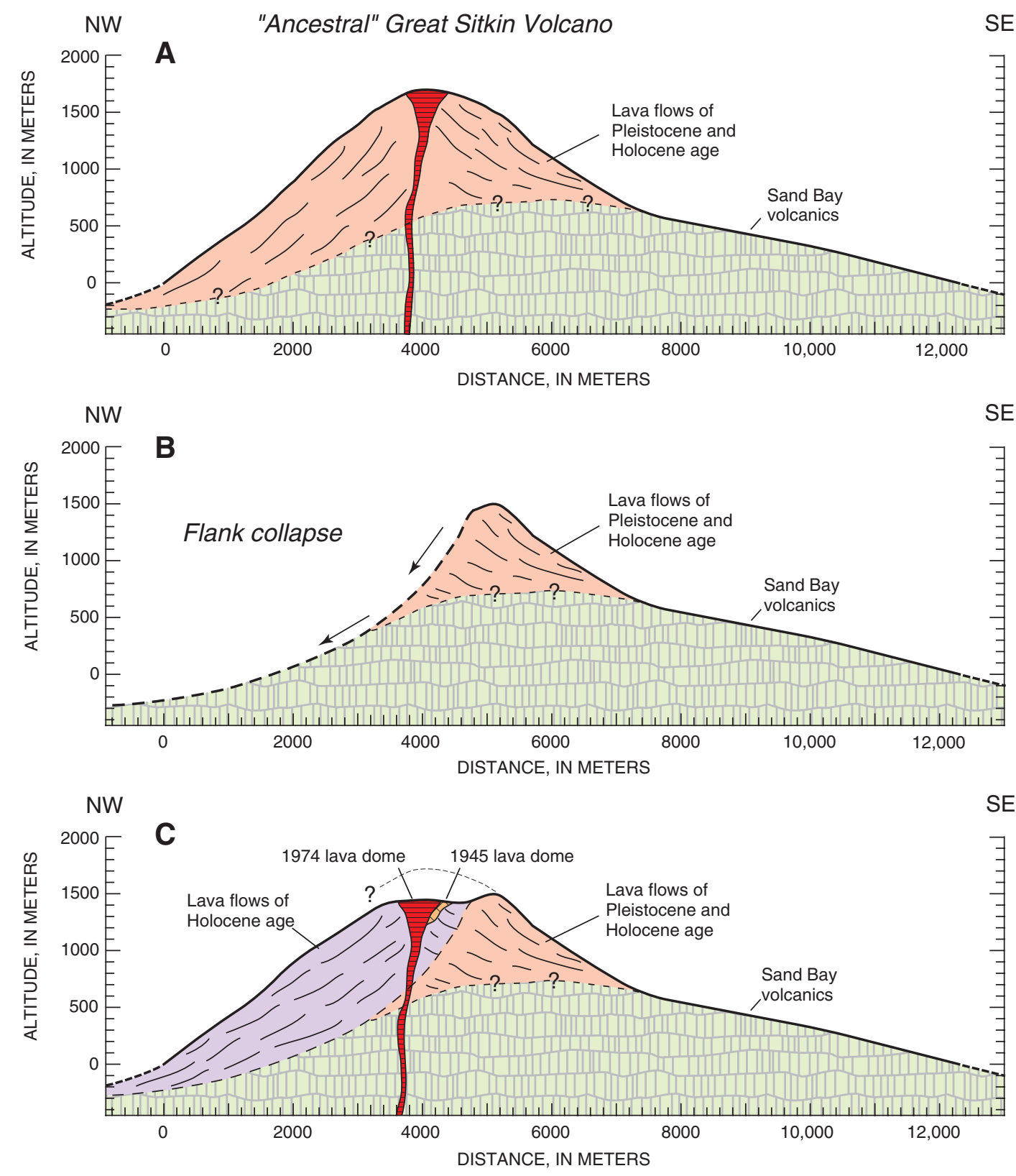

Figure 11. Schematic cross section of Great Sitkin Volcano showing the evolution of the modern edifice. A. Ancestral Great Sitkin Volcano prior to flank collapse. B. Great Sitkin Volcano after flank collapse. C. Present configuration of Great Sitkin Volcano.

\section{Pyroclastic Flows and Surges}

A pyroclastic flow is a hot, dry mixture of volcanic rock debris and gas that flows rapidly downslope (fig. 7). A pyroclastic surge is similar to and often occurs with a pyroclastic flow but has a higher gas content. Because it is mostly gas, a pyroclastic surge moves more rapidly than a pyroclastic flow and may not be confined by topography, and therefore may climb up and over ridges. Pyroclastic flows are relatively dense and generally will follow topographically low areas such as stream valleys. Because they are hot (several hundred degrees Celsius) and fast moving, both pyroclastic flows and surges could be lethal to anyone on Great Sitkin Island during an eruption.

During explosive Plinian-style eruptions characterized by high, vertical eruption columns, the more dense portion of the eruption column will collapse and 

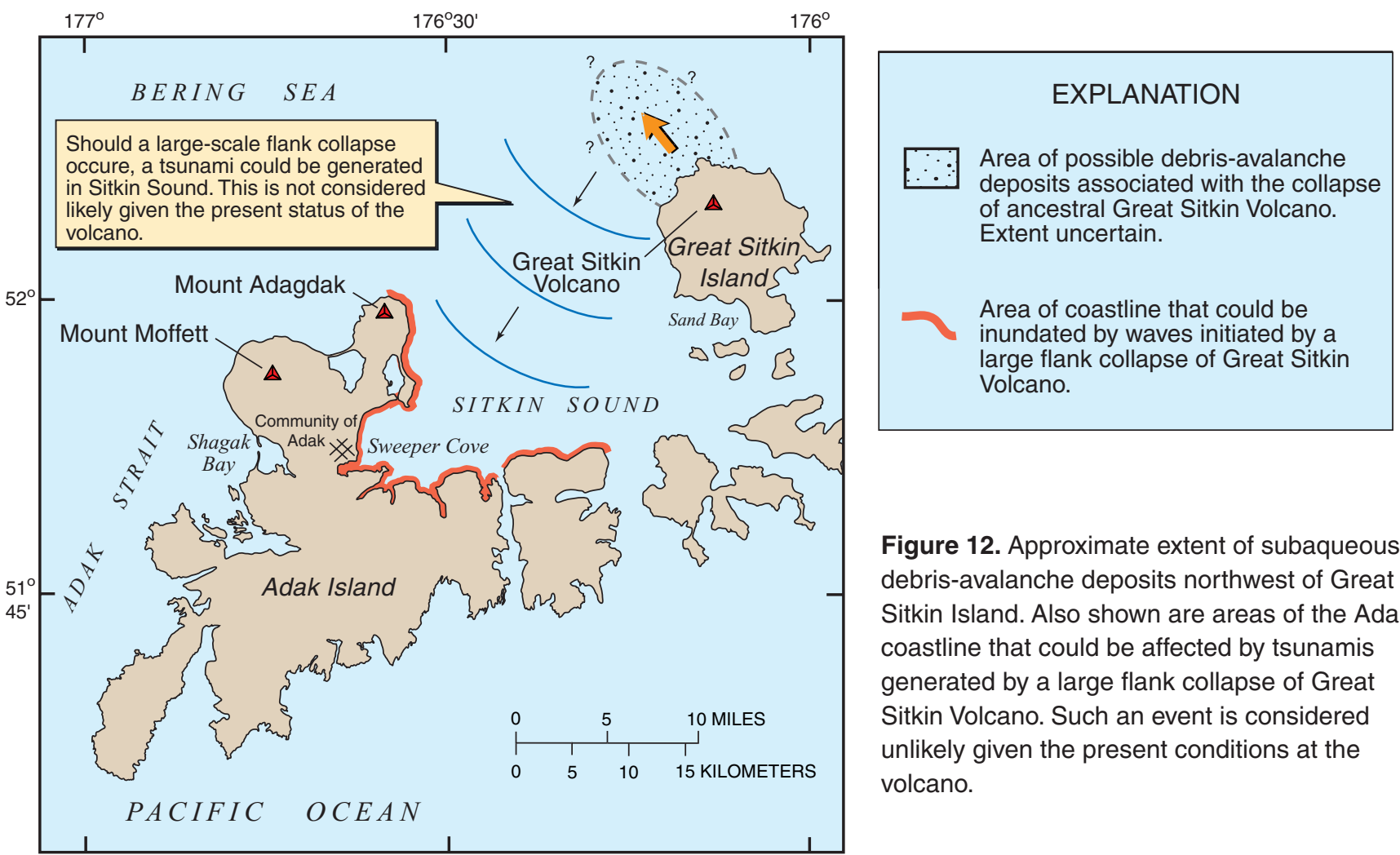

Figure 12. Approximate extent of subaqueous debris-avalanche deposits northwest of Great Sitkin Island. Also shown are areas of the Adak coastline that could be affected by tsunamis generated by a large flank collapse of Great Sitkin Volcano. Such an event is considered unlikely given the present conditions at the volcano.

fall back toward the volcano, forming a fast-moving pyroclastic flow. Pyroclastic flows of this type have a greater areal extent, can sweep all sides of the volcano, and are more likely to be directed by topographically low areas like river valleys.

Pyroclastic flows at Great Sitkin Volcano also may form by collapse of recently extruded lava dome. Lava domes are plug-like masses of molten rock that are sluggishly extruded from the vent during an eruption. As the domes are extruded, their outer margins often become oversteepened and unstable. This leads to failure of the lava dome by gravitational collapse and results in the rapid release of hot, pressurized gas and rock debris from inside the cooling lava dome, which forms a type of pyroclastic flow called a blockand-ash flow. Lava domes extruded during eruptions in 1945 and 1974 (fig. 6) were not large enough to produce significant flank failures, and no known pyroclastic flows were generated

The hazard zone for pyroclastic flows generated by dome collapse is the same as the hazard zone for pyroclastic flows generated by eruption column collapse (fig. 14). Pyroclastic flows generated by dome collapse usually affect only a specific sector of the vol- cano and typically do not have the broad areal extent common to pyroclastic flows initiated by eruption column collapse. Lava domes are present on the northwest and northeast flanks of Great Sitkin Volcano (fig. 14) and these could be sites of future eruptive activity should conditions at the volcano change. We found no evidence of recent eruptions from these areas. If flank eruptions occur in the future, new lava domes could develop and they may initiate pyroclastic flows if they collapse. The flows likely will be small and confined to areas immediately downslope from the lava dome and may travel only a few kilometers from their source.

Small-volume pyroclastic flows may have been generated from eruptions of the summit crater, possibly as recently as 1792 . Pumiceous pyroclastic-flow deposits are present at a variety of locations on the north, west, southwest, and east flanks of the volcano (fig. 14). Pyroclastic-flow deposits exposed at the mouth of Glacier Creek contained charcoal that yielded a radiocarbon age of 300-500 yr B.P., indicating that a pyroclastic eruption of Great Sitkin Volcano occurred within the past 500 years. Pumiceous pyroclastic-flow deposits on the north side of Great Sitkin 


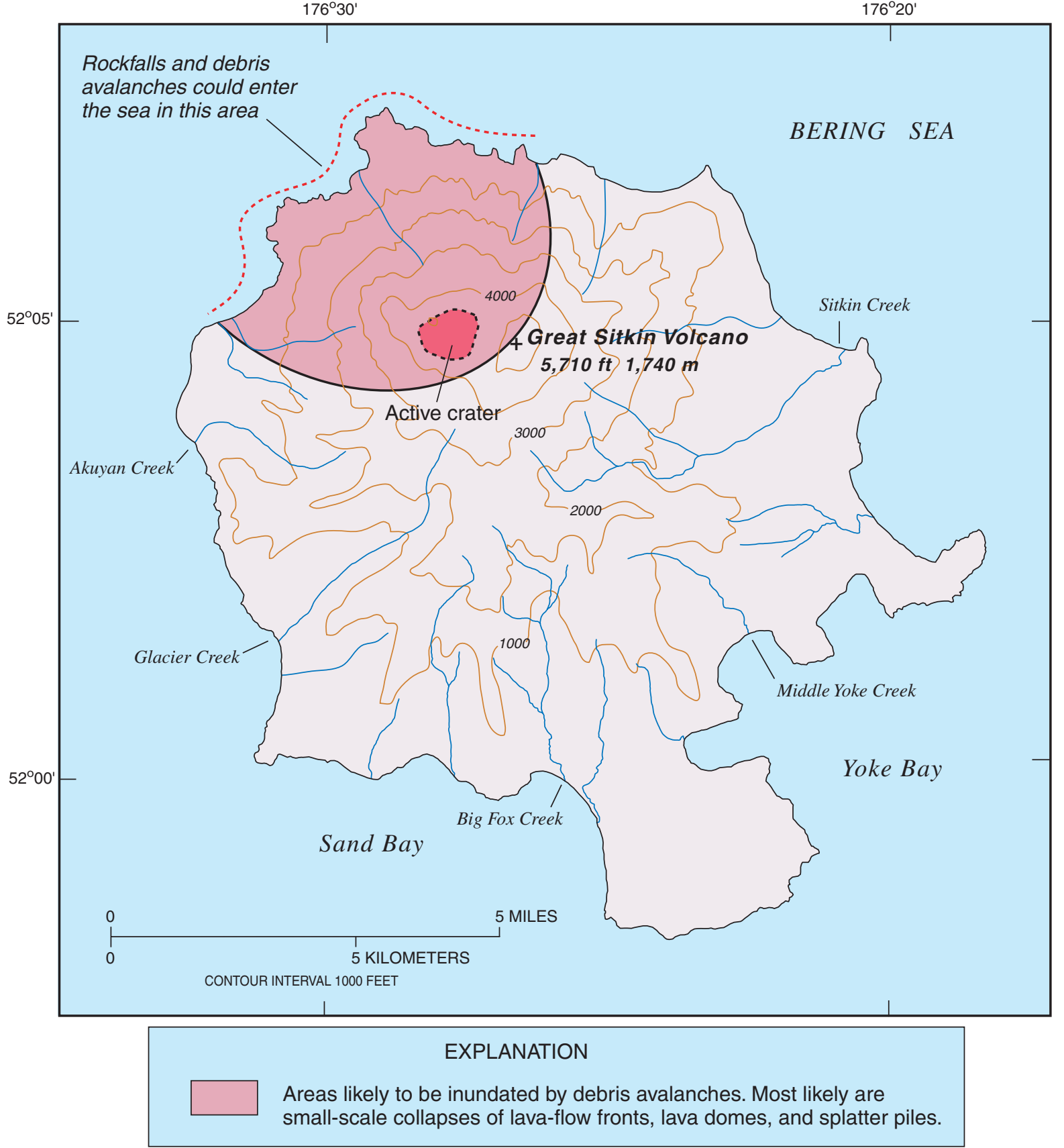

Figure 13. Areas of Great Sitkin Island that could be swept by debris avalanches and rockfall.

Island were produced by flows that followed large lava-flow levees (fig. 4). The pyroclastic flows probably were produced by the collapse of explosive eruption columns and may have traveled out over the sea, although their exent is not known. Fresh-appearing pyroclastic-flow deposits also are preserved on the northwest flank of the volcano where they form a patchy, discontinuous cover over lava flows and talus.
Pyroclastic flows and surges from most eruptions would be expected to reach at least several kilometers beyond the vent and could travel in almost any direction (fig. 14). The runout distance of pyroclastic flows is estimated by determining the ratio of the fall height (H) (usually assumed to be the volcano summit) to the runout distance (L) of known flows, where typical H/L values are between 0.2 and 0.3 (Hayashi and Self, 1992; Hoblitt and others, 1995). These values give 

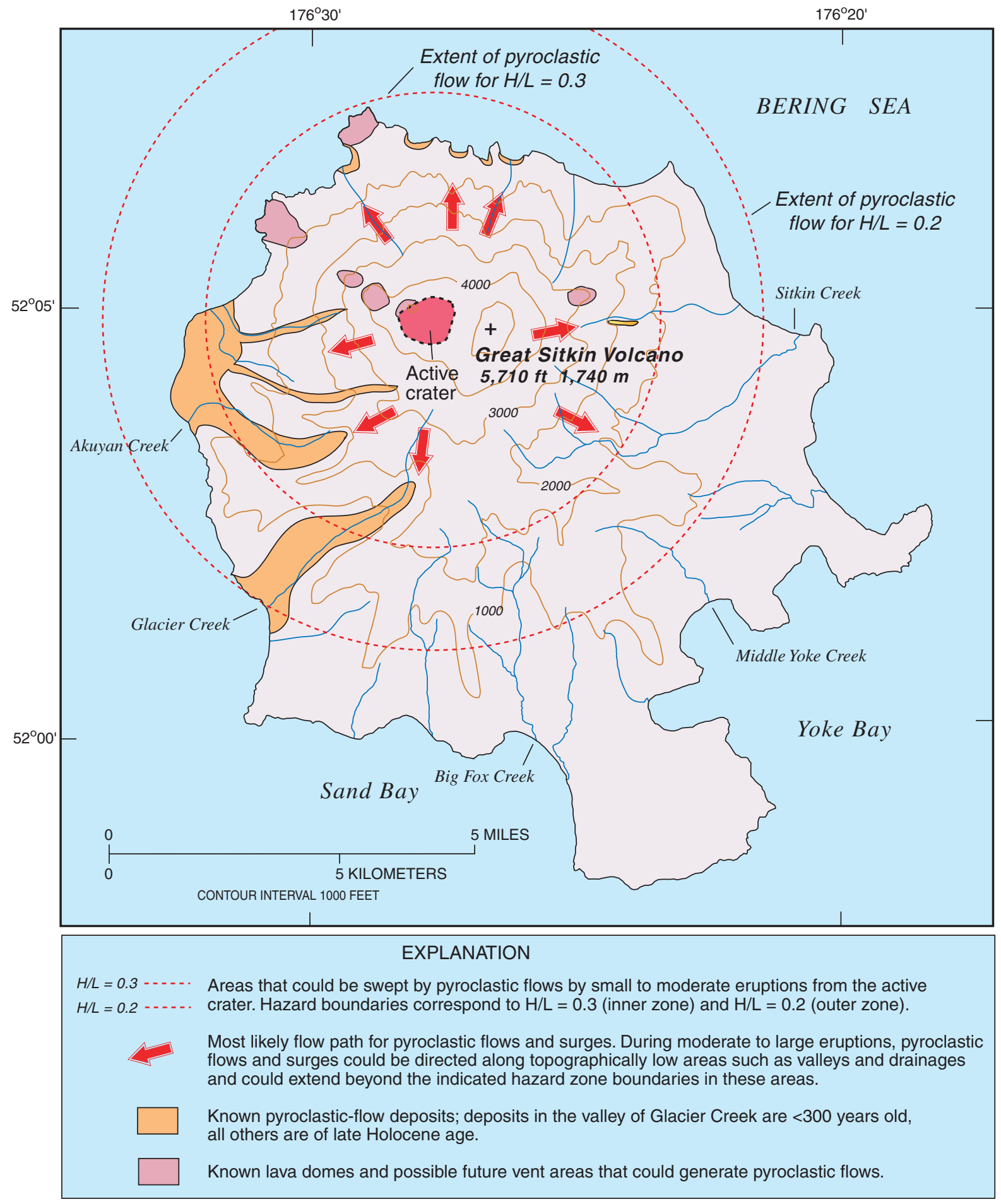

Figure 14. Areas of Great Sitkin Island that could be affected by pyroclastic flows.

runout distances of about 5 to 8 kilometers for pyroclastic flows erupted from the crater on Great Sitkin Volcano and are most relevant to pyroclastic flows that move over irregular landscapes. Pyroclastic flows directed north from the summit of Great Sitkin Volcano soon would encounter water and may travel a greater distance than they do on land. Very voluminous pyroclastic flows that enter the sea may initiate tsunamis (Waythomas and Neal, 1998), but this is not likely to happen during typical eruptions of Great Sitkin Volcano. 
It is difficult to accurately predict the extent of a pyroclastic surge. They are commonly associated with pyroclastic flows and have a slightly greater lateral extent. The location of the hazard boundary for a pyroclastic surge is uncertain and is not shown on figure 14 or plate 1 . The boundary is conservatively approximated by the hazard boundary for a pyroclastic flow, although a pyroclastic surge is expected to extend beyond this boundary, perhaps by several kilometers or more. Pyroclastic surges are hot $\left(300^{\circ}\right.$ to $800^{\circ} \mathrm{C}$ ) and gaseous, and death or injury from asphyxiation and burning is likely. Because the surge cloud may travel very fast (at least tens of meters per second), may detach itself from the pyroclastic flow, and may surmount topographic barriers, pre-eruption evacuation of Great Sitkin Island is the only way to eliminate risk from pyroclastic surges.

\section{Directed Blasts}

A directed blast is a large-scale, lateral volcanic explosion caused by a major landslide or slope failure that uncaps the internal vent system of the volcano. Such an event is rare in the history of a volcano.

Although geologic evidence indicates that at least one major slope failure has occurred at Great Sitkin Volcano, direct evidence for a directed blast has not been discovered. The hazard zone boundary showing the area most likely to be affected by a directed blast (fig. 15) is based on data from the 1980 eruption of Mount St. Helens in Washington. The directed blast associated with the 1980 Mount St. Helens eruption is one of the largest known historical directed blast events and, thus, is a "worst case" example. If a directed blast were to occur from Great Sitkin Volcano, it could affect a broad area, possibly a $180^{\circ}$ sector from the vent. Should a directed blast occur at Great Sitkin Volcano, it is likely to be directed the north-northwest and originate from the northwest sector of the volcano which has been most recently active (fig. 15). A directed blast usually will happen in the first few minutes of an eruption, thus, give no time for warning or evacuation once the eruption is imminent. Living things in the path of a directed blast will be killed or destroyed by impact, burning, abrasion, burial, and heat.

\section{Volcanic Gases}

Gases are emitted by most active volcanoes, because magma contains dissolved gas and boils off shallow ground water that typically is present in the edifice of the volcano. The most common volcanic gases are water vapor, carbon dioxide, carbon monoxide, sulfur dioxide, and hydrogen sulfide. Volcanic sulfur and halide gases that encounter water can form large amounts of sulfuric acid $\left(\mathrm{H}_{2} \mathrm{SO}_{4}\right)$ and minor amounts of hydrochloric acid (HCI) and hydrofluoric acid (HF) as aerosols or droplets. In high concentrations, carbon dioxide, hydrogen sulfide, and sulfur dioxide may be harmful or toxic to humans and may affect areas immediately downwind from the volcano. Acid precipitation may develop from the mixing of snow or rain with acidic volcanic aerosols, which may cause various types of skin and respiratory irritations and cause corrosive damage to materials. Wind tends to disperse volcanic gas, so it typically is not found near the ground in concentrations hazardous to humans or animals more than about 10 kilometers from the volcano. During large eruptions, significant volumes of gas can travel high in the atmosphere downwind from the volcano for days and thousands of kilometers.

During trips to the crater of Great Sitkin Volcano, people reported smelling "acrid gas", most likely sulfur dioxide (Simons and Mathewson, 1955). Gas emission from the crater is normal, and the hazard from volcanic gases is unlikely to be greater than that posed by other volcanic phenomena. Gases may become trapped within the summit crater if the air is calm and could be hazardous to someone in the crater at that time. However, frequent windy conditions usually inhibit localized buildup of volcanic gas. Therefore, the hazard from volcanic gases is minor.

In addition to the active crater, volcanic gases could be emitted from an area of fumaroles, mud pots, and hot springs present on the south flank of Great Sitkin Volcano, at the head of Big Fox Creek (52 $02^{\circ}$ 10 ” N, $176^{\circ} 05^{\prime} 40^{\prime \prime} \mathrm{W}$; pl. 1). The fumarolic area was not visited during our work in 1999 and 2000, but Simons and Mathewson (1955) reached the area in 1946 and measured the temperature and $\mathrm{pH}$ of the hot springs. In 1946, the range in temperature of 12 hot springs was $88^{\circ}$ to $98^{\circ} \mathrm{C}$ and, in $\mathrm{pH}$, from 2 to 7 . 


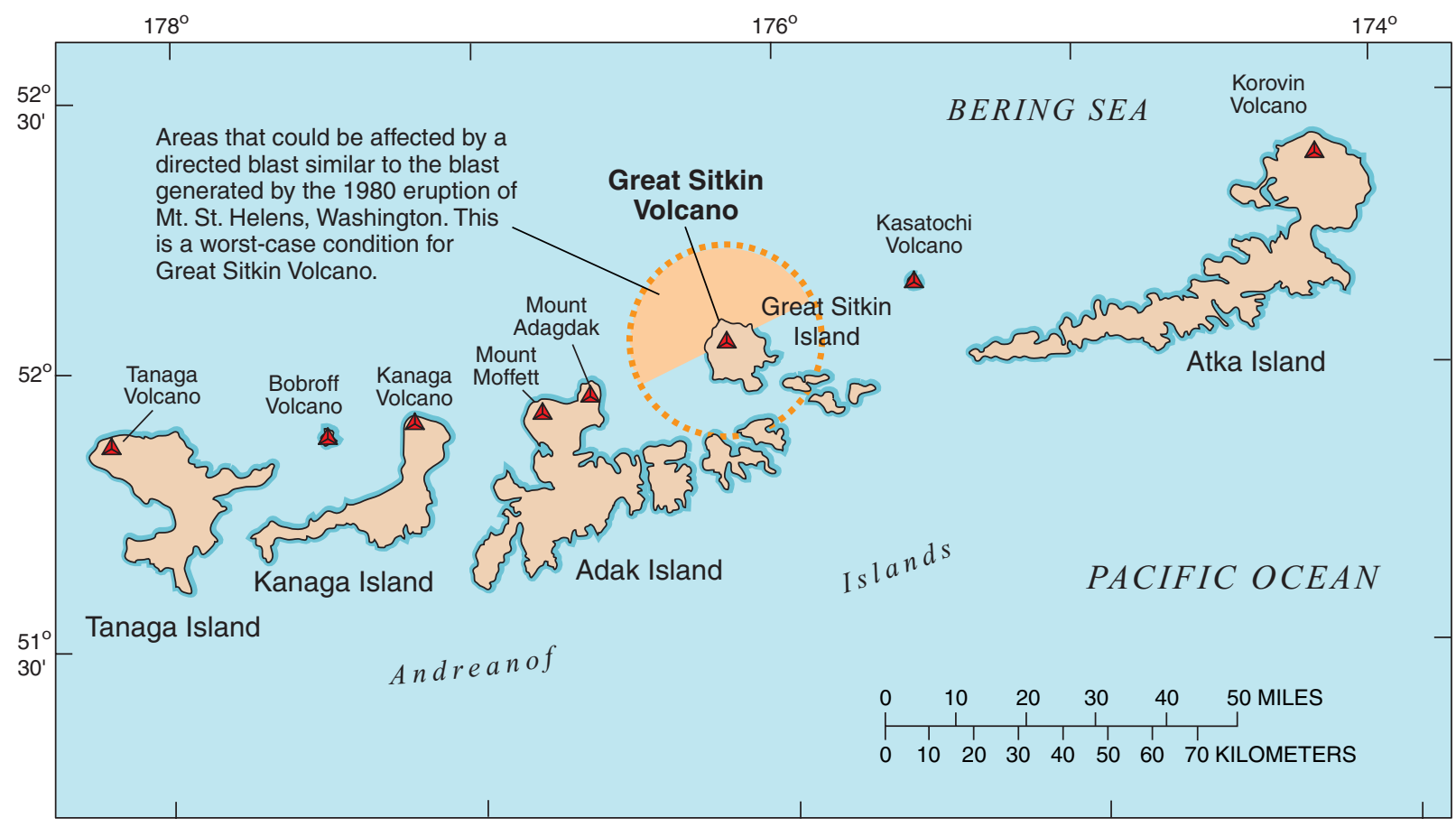

Figure 15. Areas near Great Sitkin Island that could be affected by directed blasts.

Because the fumaroles and hot springs remain active, the temperature, $\mathrm{pH}$, and chemical composition of the water and gases could reach hazardous levels in a short amount of time (days to weeks), and entering this area could be hazardous.

\section{Lava Flows}

Streams of molten rock or lava are likely to form during a future eruption of Great Sitkin Volcano and, in general, lava flows develop after explosive activity at the volcano declines. Most of Great Sitkin Volcano is composed of lava flows (figs. 4), mainly of andesitic composition. Typical lava flows on the north flank of Great Sitkin Volcano are lobate accumulations of blocky aa lava that extend from the summit of the volcano for several kilometers and, in some areas, terminate in the sea. Future eruptions from vents within the crater could generate enough lava to fill and overtop the crater. Although this was reported to have happened during the 1974 eruption, no young lava flows were observed outside the crater. Future eruptions probably will generate lava flows similar to those preserved on the volcano, and these flows are expected to move slowly downslope, probably not more than a few tens of meters per hour. Lava flows of this type pose little hazard to people who could easily walk from them; however, lava flows may develop steep fronts and could shed hot blocks and debris downslope. Lava flows that reach snow, ice, or the ocean may initiate minor steam explosions.

\section{EVENT FREQUENCY AND RISK AT GREAT SITKIN VOLCANO}

Eruptions of Great Sitkin Volcano should be expected in the future, but the timing of the next eruption is uncertain. The primary hazards during a future eruption will be clouds of volcanic ash, ash fall, ballistic fallout, pyroclastic flows, and lahars. Because Great Sitkin Island is uninhabited and no permanent structures or facilities are present, only the communities of Adak and Atka could be at direct risk from future eruptions. During any future eruption, ash could fall on the communities of Adak and Atka and several millimeters of ash could accumulate downwind from the volcano.

Should a sustained explosive eruption occur, clouds of volcanic ash would be generated that could 


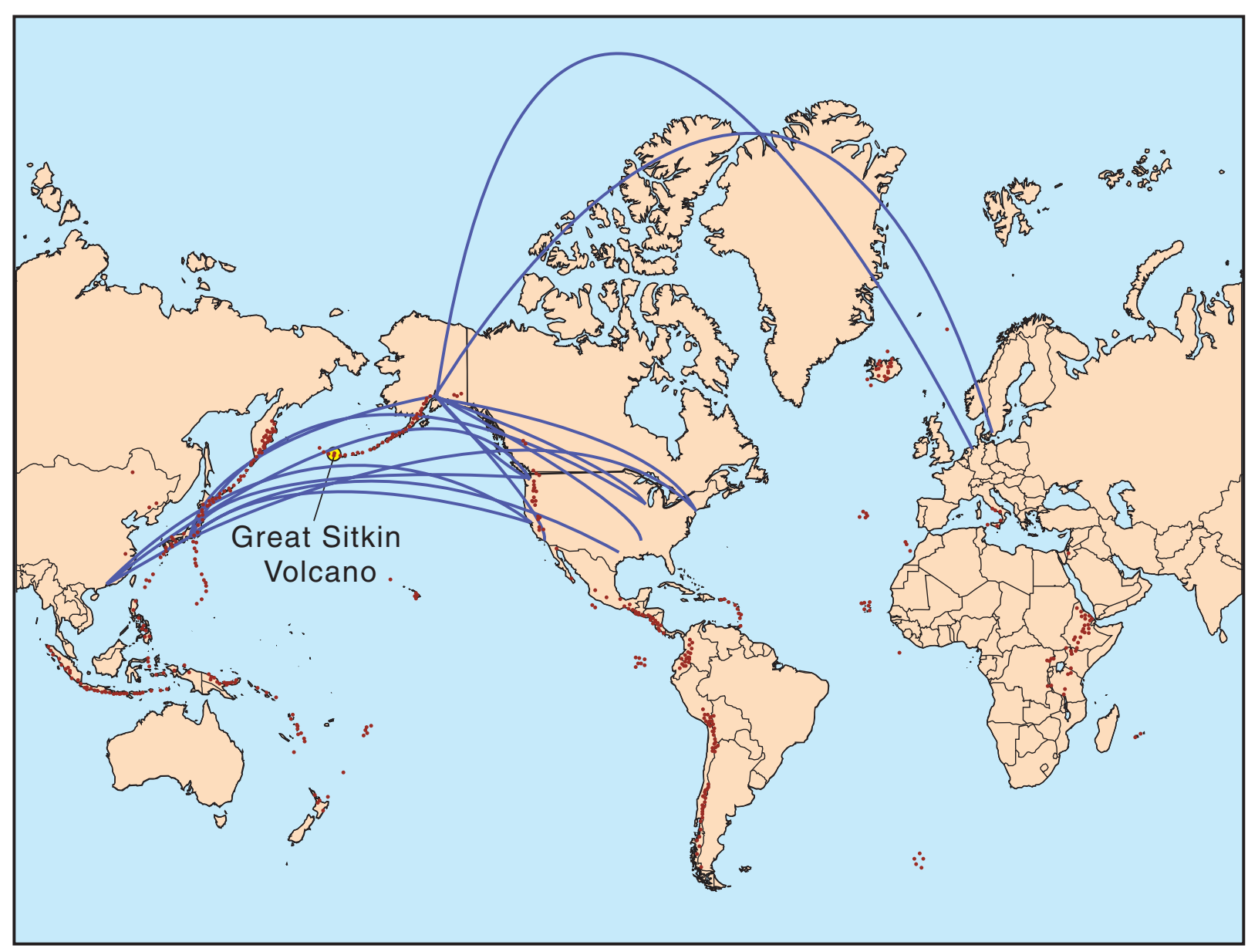

EXPLANATION

Principal air routes

$\therefore$ Other active volcanoes

Figure 16. Principal North Pacific air routes in relation to Great Sitkin Volcano.

drift hundreds and possibly thousands of kilometers downwind. All aircraft, boats, some facilities, and living things-including humans-downwind from the volcano would be at risk from effects of volcanic-ash clouds and ash fallout. Ash clouds from Great Sitkin Volcano could rise to altitudes of 15,000 meters or more and move into the flight paths of aircraft using the Adak airfield or flying North Pacific air routes (fig. 16). The frequency at which dangerous clouds of volcanic ash are produced and the amount of ash fall cannot be estimated with certainty. Signs of volcanic unrest, such as elevated levels of earthquake activity, a change in emission rate and volume of volcanic gas, or an increase in ground temperature at or near the vent, usually will precede an eruption. This will permit reasonable estimates of the likelihood of volcanic ash emission once an eruptive phase is detected. However, it is not possible to determine the characteristics of an ash cloud before an eruption occurs, except that they are likely to be similar to those generated by historical eruptions of Great Sitkin Volcano and other similar Aleutian arc volcanoes.

\section{HAZARD WARNING AND MITIGATION}

Typically, eruptions at most Aleutian arc volcanoes are preceded by weeks to months of precursory earthquake activity, giving some degree of seismic warning prior to an eruption. Many eruptions also are preceded by at least several weeks of increased gas emission from the summit area. When volcanic unrest 
is detected, other monitoring techniques, such as satellite observations, measurement of volcanic-gas flux, remote observation with real-time video or time-lapse cameras, and geodetic surveying, are used to develop a comprehensive assessment of the likelihood of an eruption and its potential effects.

The Alaska Volcano Observatory (AVO) monitors Great Sitkin Volcano with a real-time seismic network. A network of six radio-telemetered seismometers sends real-time data to the AVO offices in Anchorage and Fairbanks. Satellite images of the volcano are analyzed twice daily to determine the presence of anomalous thermal areas and airborne volcanic ash.

One of the primary roles of the AVO is to communicate timely warnings of volcanic unrest and potential eruptions (Eichelberger and others, 1995, p. 4). The AVO distributes by fax and electronic mail a weekly update of volcanic activity that summarizes the status of the currently monitored volcanoes and some historically active but unmonitored volcanoes along the Aleutian volcanic arc. During periods of unrest or volcanic crises, updates are issued more frequently to advise the public of significant changes in activity. Recipients of these updates include the Federal Aviation Administration, air carriers, the National Weather Service, the Alaska Department of Emergency Services, local military bases, the Governor's office, various State offices, television and radio stations, news wire services, and others. Updates also are distributed by electronic mail to various volcano information networks and are posted on the AVO World Wide Web site (URL: <http://www.avo.alaska.edu>).

During the 1989-90 eruptions of Redoubt Volcano, the AVO developed a "level-of-concern color code" (Brantley, 1990; table 2). This code provides efficient and simple information about the status of volcanic activity or unrest and conveys the AVO's interpretation of that activity or unrest in terms of the potential for an eruption and its likely effects. In the event of a volcanic crisis, various Federal, State, and local officials are contacted by telephone and advised of the situation, and the level-of-concern color code is established while an update is being prepared. This approach has been used successfully during recent eruptions at monitored volcanoes such as Redoubt Volcano (1989-90), Crater Peak (1992), Pavlof Volcano (1996), and Shishaldin Volcano (1999).
Minimizing the risks posed by eruptions of Great Sitkin Volcano is possible through 1) understanding potential hazards, 2) adequate warning of eruptive activity, and 3) preparing for an eruption. Areas within about 10-20 kilometers of the volcano are at risk from all hazardous volcanic phenomena. Knowledge of potential hazards is required to assess the risk associated with a specific location on or near the volcano and to assess whether movement to another location would be safer. Recreational users of the area around Great Sitkin Volcano should recognize that all areas within about 20 kilometers of the volcano, as well as all areas downwind from the summit, are subject to tephra and ballistic fallout. Low-lying terrain along streams and gullies that extend toward the summit of the volcano is subject to pyroclastic flows and surges, lahars, lava flows, and rock avalanches. During an eruption, access closer than about 10 kilometers from the volcano could be impossible and the risks to human life great. People in small planes, helicopters, and boats seeking a view of an eruption could be at risk from intermittent and unpredictable discharge of ballistic projectiles (volcanic bombs), pyroclastic flows, or sudden changes in the travel direction of the eruption plume.

People located farther away from the volcano may have additional time to prepare for the adverse effects of an eruption; however, an emergency plan developed and ready prior to the onset of an eruption is useful. The planning for volcanic emergencies is similar to that for other emergencies, such as flooding or extreme weather. The sources of emergency information are often the same and the usual interruption of essential services may result. Thus, planning for interruptions in electrical service, transportation (especially air travel), and outdoor activities is appropriate for volcanic emergencies. 
Table 2. Alaska Volcano Observatory Level-of-Concern color code

\begin{tabular}{|c|c|c|}
\hline Color & $\begin{array}{l}\text { Intensity of unrest } \\
\text { at volcano }\end{array}$ & Forecast \\
\hline GREEN & $\begin{array}{l}\text { Volcano is in quiet, } \\
\text { "dormant" state. }\end{array}$ & No eruption anticipated. \\
\hline YELLOW & $\begin{array}{l}\text { Small earthquakes } \\
\text { detected locally } \\
\text { and (or) increased } \\
\text { levels of volcanic- } \\
\text { gas emissions. }\end{array}$ & $\begin{array}{l}\text { Eruption is possible in } \\
\text { next few weeks and } \\
\text { may occur with little or } \\
\text { no additional warning. }\end{array}$ \\
\hline ORANGE & $\begin{array}{l}\text { Increased numbers of } \\
\text { local earthquakes. } \\
\text { Extrusion of lava } \\
\text { dome or lava flows } \\
\text { (nonexplosive erup- } \\
\text { tion) may be occur- } \\
\text { ring. }\end{array}$ & $\begin{array}{l}\text { Explosive eruption is pos- } \\
\text { sible within a few days } \\
\text { and may occur with lit- } \\
\text { tle or no warning. Ash } \\
\text { plume(s) not expected } \\
\text { to reach } 7,600 \text { meters } \\
\text { ( } 25,000 \text { feet) above sea } \\
\text { level. }\end{array}$ \\
\hline RED & $\begin{array}{l}\text { Strong earthquake } \\
\text { activity detected } \\
\text { even at distant mon- } \\
\text { itoring stations. } \\
\text { Explosive eruption } \\
\text { may be in progress. }\end{array}$ & $\begin{array}{l}\text { Major explosive eruption } \\
\text { expected within } 24 \\
\text { hours. Large ash } \\
\text { plume(s) expected to } \\
\text { reach at least } 7,600 \\
\text { meters }(25,000 \text { feet) } \\
\text { above sea level. }\end{array}$ \\
\hline
\end{tabular}

\section{REFERENCES CITED}

Becker, G.F., 1898, Reconnaissance of the gold field of southern Alaska, with some notes on general geology: U.S. Geological Survey 18th Annual Report pt. 3, p. 1-86.

Bering Sea EEZ-SCAN Scientific Staff, 1991, Atlas of U.S. Exclusive Economic Zone, Bering Sea: U.S. Geological Survey Miscellaneous Investigations Series I-2053.

Blong, R.J., 1984, Volcanic hazards-A sourcebook on the effects of eruptions: Academic Press, Sydney, $424 \mathrm{p}$.

Brantley, S.R., ed., 1990, The eruption of Redoubt Volcano, Alaska, December 14, 1989-August 31, 1990: U.S. Geological Survey Circular 1061, 33 p.

Byers, F.M., Jr., and Brannock, W.W., 1949, Volcanic activity on Umnak and Great Sitkin Islands, 1946-1948. Transactions-American Geophysical Union, v. 30, p. 719-734.

Casadevall, T.J., ed., 1994, Volcanic ash and aviation safety-Proceedings of the First International Symposium on Volcanic Ash and Aviation Safety, Seattle, Washington, July 1991: U.S. Geological Survey Bulletin 2047, 450 p.

Coats, R.R., 1950, Volcanic activity in the Aleutian arc: U.S. Geological Survey Bulletin 974-B, p. 35-47. 1956, Geology of northern Adak Island, Alaska: U.S. Geological Survey Bulletin 1028-C, 67 p.
Eichelberger, J.C., Keith, T.E.C., Miller, T.P., and Nye, C.J., 1995, The 1992 eruption of Crater Peak vent, Mount Spurr volcano, Alaska: chronology and summary, in Keith, T.E.C., ed., The 1992 eruptions of Crater Peak vent, Mount Spurr volcano, Alaska: U.S. Geological Survey Bulletin 2139, p. 1-18.

Grewingk, Constantine, 1850, Beitrag zur Kenntniss der orographischen und geognostischen Beschaffenheit der Nordwestkuste Amerikas, mit den angliegenden inseln (Contribution to knowledge of the orographic [topographic] and geognostic [geologic] condition of the northwest coast of America with adjacent islands): Abstracted from Verhandlungen der Russich-Kaiserlichen Mineralogischen Gesellschalt zur St. Petersburg, Jahrgan 1848 ung 1849, p. 76-342.

Hayashi, J.N., and Self, S., 1992, A comparison of pyroclastic flow and debris avalanche mobility: Journal of Geophysical Research, v 97, p. 9063-9071.

Hoblitt, R.P., Walder, J.S., Dreidger, C.L., Scott, K.M., Pringle, P.T., and Vallance, J.W., 1995, Volcano hazards from Mount Rainier, Washington: U.S. Geological Survey Open-File Report 98-273, 12 p.

Jaggar, T.A., 1927, Eruption of Mageik in Alaska: The Volcano Letter, no. 147, Hawaiian Volcano Research Association, $1 \mathrm{p}$.

Miller, T.P., and Smith, R.L., 1987, Late Quaternary calderaforming eruptions in the eastern Aleutian arc, Alaska: Geology, v. 15, p. 434-438.

Miller, T.P., McGimsey, R.G., Richter, D.H., Riehle, J.R., Nye, C.J., Yount, M.E., and Dumoulin, J.A., 1998, Catalog of the historically active volcanoes of Alaska: U.S. Geological Survey Open-File Report 98-582, 104 p.

Myers, Barbara, Brantley, S.R., Stauffer, Peter, and Hendley, J.W., II, 1997, What are volcano hazards?: U.S. Geological Survey Fact Sheet 002-97, 2 p. (Revised 1998.)

Powers, H.A., 1958, Alaska Peninsula-Aleutian Islands, p. 61-75, in Williams, Howel, ed., Landscapes of Alaska: Their geologic evolution: Berkeley, University of California, $148 \mathrm{p}$.

Siebert, L., 1996, Hazards of large volcanic debris avalanches and associated eruptive phenomena, in Scarpa, R., and Tilling, R.I., eds., Monitoring and mitigation of volcano hazards: Berlin, Springer-Verlag, p. 541-572.

Simons, F.S., and Mathewson, D.E., 1955, Geology of Great Sitkin Island, Alaska: U.S. Geological Survey Bulletin 1028-B, $43 \mathrm{p}$.

Vallance, J.W., 1999, Postglacial lahars and potential hazards in the White Salmon River system on the southwest flank of Mount Adams, Washington: U.S. Geological Survey Bulletin 2161, 49 p. 
Vallance, J.W., and Scott, K.M., 1997, The Osceola mudflow from Mount Rainier-Sedimentology and hazard implications of a huge clay-rich debris flow: Geological Society of America Bulletin, v. 109, p. 143-163.

Waythomas, C.F., and Neal, C.A., 1998, Tsunami generation during the $3500 \mathrm{yr}$. B.P. caldera-forming eruption of Aniakchak volcano, Alaska. Bulletin of Volcanology, v.60, p. 110-124.

\section{GLOSSARY}

Andesite. A fine-grained volcanic rock made up of feldspars and ferromagnesian minerals; by definition has a silica content of 54 to about 62 percent.

Ash. Fine fragments (less than 2 millimeters across) of volcanic rock formed in an explosive volcanic eruption. Ash particles are typically sharp, angular, and abrasive, and are composed of volcanic glass, mineral, and rock fragments.

Block-and-ash flow. A pyroclastic flow that contains blocks of primary volcanic rock in coarse, ashy matrix. Blockand-ash flows usually form from a collapsing lava dome.

Debris avalanche. Rapidly moving, dry flows of disaggregated rock debris, sand, and silt. Volcanic debris avalanches often form by some type of structural collapse of the volcano, usually the steep front of the cooled lava dome, or other parts of upper edifice. A large portion of the volcano may become unstable, break away from the volcanic massif, and become an avalanche. A debris avalanche may be triggered by an eruption or earthquake. Debris avalanches move at velocities ranging from a few tens of meters per second to more than 100 meters per second and behave like complex granular flows or slide flows. Often they are quite voluminous (greater than 10 cubic kilometers) and may run out considerable distances (up to 85 kilometers) from their source. The resulting debris avalanche deposit usually exhibits hummocky surface morphology.

Directed blast. Large-scale volcanic explosions caused by a major landslide or slope failure that results in rapid drop in the pressure of the intruding magma or hydrothermal system near the surface of the volcanic edifice. The 1980 eruption of Mount St. Helens was triggered by massive slope failure, and subsequent laterally directed blast affected a $180^{\circ}$ sector north of volcano and extended for several tens of kilometers outward. A directed blast typically travels away from the volcano at a low angle and may not be deflected by ridges or other topographic barriers. Rock debris propelled by directed blast moves much faster than typical landslides and rockfalls. For example, at Mount St. Helens, initial velocity of directed blast cloud was about 600 kilometers per hour and decreased to about 100 kilometers per hour at a distance 25 kilometers from volcano.

Edifice. The upper part of the volcanic cone, including the vent and summit areas.

Eruption cloud. Cloud of gas, ash, and other fragments that forms during an explosive volcanic eruption and travels long distances with the prevailing winds.

Eruption column. The vertical portion of the eruption cloud that rises above a volcanic vent.

Fallout. A general term for debris that falls to Earth's surface from an eruption cloud.

Holocene. An epoch of Earth's history that began 10 thousand years ago and includes the present.

Lahar. An Indonesian term for a wet debris flow containing angular clasts of volcanic material. For the purposes of this report, a lahar is any type of sediment/water mixture originating on or from the volcano. Most lahars move rapidly down the slopes of a volcano as channelized flows and deliver large amounts of sediment to the rivers and streams that drain the volcano. The flow velocity of some lahars may be as high as 20 to 40 meters per second (Blong, 1984), and sediment concentrations of greater than 750,000 parts per million are not uncommon. Large-volume lahars can travel great distances if they have an appreciable clay content (greater than 3 to 5 percent), remain confined to a stream channel, and do not significantly gain sediment while losing water. Thus, they may affect areas many tens to hundreds of kilometers downstream from a volcano.

Lapilli. Ejected rock or pumice fragments 2 to 64 millimeters in diameter.

Lava. Molten rock that reaches Earth's surface.

Lava dome. A steep-sided mass of viscous and often blocky lava extruded from a vent; typically has a rounded top and roughly circular outline.

Magma. Molten rock beneath Earth's surface.

Pleistocene. The period of Earth history between 1.8 million and 10 thousand years before present. Pleistocene age refers to geologic deposits formed during the Pleistocene epoch.

Plinian. Volcanic eruptions associated with highly explosive ejecta of tephra and large-volume emissions of ash. Ash plumes from Plinian eruptions usually reach 10,000 to 45,000 meters in height above the vent. A sub-Plinian eruption is similar, but the total volume of material erupted and the maximum height of the eruption column are less.

Pumice. Highly vesicular, silica-rich, volcanic ejecta; due to its extremely low density, it often floats on water.

Pyroclastic. General term applied to volcanic products or processes that involve explosive ejection and fragmentation of erupting material. 
Pyroclastic flow. A dense, hot, chaotic avalanche of rock fragments, gas, and ash that travels rapidly away from an explosive eruption column, often down the flanks of the volcano (synonymous with "ash flow"). Pyroclastic flows move at speeds ranging from 10 to several hundred meters per second and are typically at temperatures of $300^{\circ}$ to $800^{\circ} \mathrm{C}$ (Blong, 1984). Pyroclastic flows form either by collapse of eruption column or by failure of the front of cooling lava dome. Once these flows are initiated, they may travel distances of several kilometers or more and easily override topographic obstacles in the flow path. A person could not outrun an advancing pyroclastic flow.

Pyroclastic surge. A low-density, turbulent flow of finegrained volcanic rock debris and hot gas. Pyroclastic surges differ from pyroclastic flows in that they are less dense and tend to travel as low, ground-hugging, but highly mobile cloud that can surmount topographic barriers. Surges often affect areas beyond the limits of pyroclastic flows.

Quaternary. A period of Earth's history that began about 1.8 million years ago and includes the present. The Quaternary period is subdivided into the Pleistocene and Holocene epochs.

Radiometric dating. A technique for determining the age of formation of volcanic rocks based on measuring the amounts of radiogenic isotopes that decay at known rates.

Stratocone. A steep-sided volcano, usually conical in shape, built of lava flows and fragmental deposits from explosive eruptions. Also called a stratovolcano or composite cone.

Tephra. Any type of rock fragment that is ejected forcibly from the volcano during eruption. Tephra may be finegrained dust or "ash" ( 0.0625 to 2 millimeters in diameter, or silt to sand sized); coarser lapilli (2 to 64 millimeters in diameter, or sand to pebble sized); or consist of large blocks or bombs (greater than 64 millimeters, or cobble to boulder sized). When tephra is airborne, the coarsest fraction will be deposited close to volcano, but fine fraction may be transported long distances and can stay suspended in atmosphere for many months.

Tertiary. A period of Earth's history beginning about 66.4 million years ago and ending about 1.8 million years ago.

Vent. Opening in Earth's surface through which magma erupts or volcanic gases are emitted. 


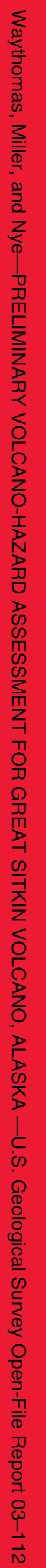

